\title{
Voltage-Induced $\mathrm{Ca}^{2+}$ Release in Postganglionic Sympathetic Neurons in Adult Mice
}

\author{
Hong-Li Sun ${ }^{1,2}$, Wen-Chin Tsai ${ }^{3,4}$, Bai-Yan Li ${ }^{5}$, Wen Tao ${ }^{1}$, Peng-Sheng Chen ${ }^{3}$, \\ Michael Rubart ${ }^{1 *}$
}

1 Riley Heart Research Center, Herman B. Wells Center for Pediatric Research, Indiana University School of Medicine, Indianapolis, Indiana, United States of America, 2 Department of Pharmacology, Harbin Medical University-Daqing, Daqing, Heilongjiang, China, 3 The Krannert Institute of Cardiology and Division of Cardiology, Department of Medicine, Indiana University School of Medicine, Indianapolis, Indiana, United States of America, 4 Division of Cardiology, Department of Medicine, Hualein Tzu-Chi General Hospital, Hualein, Taiwan, 5 Department of Biomedical Engineering, Indiana University-Purdue University at Indianapolis, Indianapolis, Indiana, United States of America

* mrubartv@iu.edu

\section{G openaccess}

Citation: Sun H-L, Tsai W-C, Li B-Y, Tao W, Chen P$S$, Rubart M (2016) Voltage-Induced $\mathrm{Ca}^{2+}$ Release in Postganglionic Sympathetic Neurons in Adult Mice. PLOS ONE 11(2): e0148962. doi:10.1371/journal. pone. 0148962

Editor: Agustín Guerrero-Hernandez, Cinvestav-IPN, MEXICO

Received: December 24, 2014

Accepted: January 26, 2016

Published: February 9, 2016

Copyright: ๑ 2016 Sun et al. This is an open access article distributed under the terms of the Creative Commons Attribution License, which permits unrestricted use, distribution, and reproduction in any medium, provided the original author and source are credited.

Data Availability Statement: All relevant data are within the paper and its Supporting Information files.

Funding: This work was supported by grants from the National Natural Science Foundation of China (81202509, http://www.nsfc.gov.cn/) to HS and the National Heart, Lung and Blood Institute (R01HL07165, http://www.nhlbi.nih.gov/) to MR. The funders had no role in study design, data collection and analysis, decision to publish, or preparation of the manuscript.

Competing Interests: The authors have declared that no competing interests exist.

\section{Abstract}

Recent studies have provided evidence that depolarization in the absence of extracellular $\mathrm{Ca}^{2+}$ can trigger $\mathrm{Ca}^{2+}$ release from internal stores in a variety of neuron subtypes. Here we examine whether postganglionic sympathetic neurons are able to mobilize $\mathrm{Ca}^{2+}$ from intracellular stores in response to depolarization, independent of $\mathrm{Ca}^{2+}$ influx. We measured changes in cytosolic $\Delta F / F_{0}$ in individual fluo-4 -loaded sympathetic ganglion neurons in response to maintained $\mathrm{K}^{+}$depolarization in the presence $(2 \mathrm{mM})$ and absence of extracellular $\mathrm{Ca}^{2+}\left(\left[\mathrm{Ca}^{2+}\right]_{e}\right)$. Progressive elevations in extracellular $\left[\mathrm{K}^{+}\right]_{\mathrm{e}}$ caused increasing membrane depolarizations that were of similar magnitude in 0 and $2 \mathrm{mM}\left[\mathrm{Ca}^{2+}\right]_{\mathrm{e}}$. Peak amplitude of $\Delta \mathrm{F} / \mathrm{F}_{0}$ transients in $2 \mathrm{mM}\left[\mathrm{Ca}^{2+}\right]_{e}$ increased in a linear fashion as the membrane become more depolarized. Peak elevations of $\Delta \mathrm{F} / \mathrm{F}_{0}$ in $0 \mathrm{mM}\left[\mathrm{Ca}^{2+}\right]_{\mathrm{e}}$ were $\sim 5-10 \%$ of those evoked at the same membrane potential in $2 \mathrm{mM}\left[\mathrm{Ca}^{2+}\right]_{e}$ and exhibited an inverse U-shaped dependence on voltage. Both the rise and decay of $\Delta \mathrm{F} / \mathrm{F}_{0}$ transients in $0 \mathrm{mM}\left[\mathrm{Ca}^{2+}\right]_{\mathrm{e}}$ were slower than those of $\Delta \mathrm{F} / \mathrm{F}_{0}$ transients evoked in $2 \mathrm{mM}\left[\mathrm{Ca}^{2+}\right]_{\mathrm{e}}$. Rises in $\Delta \mathrm{F} / \mathrm{F}_{0}$ evoked by high $\left[\mathrm{K}^{+}\right]_{\mathrm{e}}$ in the absence of extracellular $\mathrm{Ca}^{2+}$ were blocked by thapsigargin, an inhibitor of endoplasmic reticulum $\mathrm{Ca}^{2+}$ ATPase, or the inositol 1,4,5-triphosphate $\left(\mathrm{IP}_{3}\right)$ receptor antagonists 2aminoethoxydiphenyl borate and xestospongin $\mathrm{C}$, but not by extracellular $\mathrm{Cd}^{2+}$, the dihydropyridine antagonist nifedipine, or by ryanodine at concentrations that caused depletion of ryanodine-sensitive $\mathrm{Ca}^{2+}$ stores. These results support the notion that postganglionic sympathetic neurons possess the ability to release $\mathrm{Ca}^{2+}$ from $\mathrm{IP}_{3}$-sensitive internal stores in response to membrane depolarization, independent of $\mathrm{Ca}^{2+}$ influx. 


\section{Introduction}

Calcium ions play an important role in regulating a variety of neuronal processes, including excitability, gene transcription, synaptic plasticity, growth cone behavior, synaptogenesis, and neurotransmitter release [1,2]. Neurons use both extracellular and intracellular sources of calcium. Whereas voltage-gated calcium channels and receptor-operated channels such as the NMDA receptors enable $\mathrm{Ca}^{2+}$ influx from the extracellular space, inositol 1,4,5-trisphosphate $\left(\mathrm{IP}_{3}\right)$ receptors and ryanodine receptors distributed throughout the endoplasmic reticulum membrane are responsible for releasing $\mathrm{Ca}^{2+}$ from its internal stores [1]. The mechanism for triggering $\mathrm{Ca}^{2+}$ discharge from internal stores is unknown in some cases, and it is often assumed that $\mathrm{Ca}^{2+}$-induced $\mathrm{Ca}^{2+}$ release secondary to $\mathrm{Ca}^{2+}$ entry is the prevailing mechanism underlying $\mathrm{Ca}^{2+}$ mobilization. More recent studies, however, provide evidence for the existence of a $\mathrm{Ca}^{2+}$ influx-independent, voltage-induced $\mathrm{Ca}^{2+}$ release mechanism in neurons. A skeletal muscle excitation-contraction coupling-like mechanism, wherein conformational changes of the dihydropyridine receptor directly gate the ryanodine receptor, has been reported for hippocampal neurons [3], hypothalamic magnocellular neurons [4], and ischemically injured spinal cord white matter [5]. On the other hand, voltage-induced, $\mathrm{Ca}^{2+}$ influx-independent, $\mathrm{Ca}^{2+}$ release form $\mathrm{IP}_{3}$-sensitive stores has been reported for insect dorsal unpaired median neurons [6]. Overall, these studies suggest the possibility that voltage-induced $\mathrm{Ca}^{2+}$ release from internal stores may be a more general phenomenon in neurons than previously thought.

Sympathetic ganglion neurons have been demonstrated to express both dihydropyridinesensitive L-type calcium channels [7-10] and ryanodine receptors [11,12], suggesting the possibility that a skeletal muscle-like, voltage-induced $\mathrm{Ca}^{2+}$ release occurs in these cells. Here, we tested the hypothesis that sympathetic ganglion neurons in adult mice possess the ability to mobilize $\mathrm{Ca}^{2+}$ from internal stores in response to membrane depolarization, independent of $\mathrm{Ca}^{2+}$ influx. Our results provide, to the best of our knowledge, the first evidence that postganglionic sympathetic neurons are capable of releasing $\mathrm{Ca}^{2+}$ from internal stores in response to prolonged depolarization in the absence of extracellular calcium. Surprisingly, however, this process does not require dihydropyridine or ryanodine receptors. Rather, depolarization causes $\mathrm{Ca}^{2+}$ release from $\mathrm{IP}_{3}$-sensitive internal stores, utilizing a yet to be identified plasmalemmal voltage sensor. This process may constitute a novel mechanism coupling electrical activity to a rise in intracellular $\mathrm{Ca}^{2+}$ in sympathetic neurons.

\section{Materials and Methods}

\section{Preparation of sympathetic neurons}

Sympathetic neurons were prepared in a manner previously described [13]. DBA/J mice at 2 to 3 months of age were sacrificed by cervical dislocation. The superior and stellate ganglia were removed under stereomicroscopy and immediately placed in chilled $\left(4-8^{\circ} \mathrm{C}\right)$ sympathetic complete medium [DME-F12 medium supplemented with sodium bicarbonate, HEPES, penicillin/ streptomycin, 5\% fetal bovine serum, and $\mathrm{MITO}^{+}$Serum extender (Collaborative Res, Bedford, MA, USA)]. The ganglia were then incubated for $20 \mathrm{~min}$ at $37^{\circ} \mathrm{C}$ in a Earle's Balanced Salt solution (Sigma, St. Louis, MO, USA) containing $10 \mathrm{U} / \mathrm{ml}$ papain (Worthington Biochemical Corp., Lakewood, NJ, USA), followed by a 30-min incubation in Earle's Balanced Salt solution supplemented with $1.3 \mathrm{mg} / \mathrm{ml}$ type II collagenase (Worthington) and $2.2 \mathrm{mg} / \mathrm{ml}$ dispase II (Roche, Indianapolis, IN, USA). Cells were then dissociated by trituration with a fire-polished glass Pasteur pipette in trituration solution (sympathetic complete medium containing $1.8 \mathrm{mg} /$ $\mathrm{ml}$ bovine serum albumin) and plated on poly-D-lysine-coated No.1 circular glass cover slips. The isolated neurons were maintained in $5 \% \mathrm{CO}_{2}-95 \% \mathrm{O}_{2}$ at $37^{\circ} \mathrm{C}$ in trituration solution and 
used $\sim 24$ hours after plating. All procedures were approved by the Indiana University School of Medicine Institutional Animal Care and Use Committee.

\section{Cytosolic $\mathrm{Ca}^{2+}$ imaging}

A coverslip containing sympathetic neurons was transferred to a $263-\mu l$ recording chamber (model RC-21BRFS, Warner Instruments, Hamden, CT). Cells were loaded at room temperature with fluo- 4 by incubation with the acetoxymethyl (AM) ester form of the dye (fluo-4/AM; Life Technologies, Grand Island, NY) at a final concentration of $2 \mu \mathrm{M}$ in normal Tyrode's solution. After $20 \mathrm{~min}$, cells were washed several times with dye-free Tyrode's solution and transferred to an inverted microscope (Axioscope) equipped with a Zeiss x63 1.4 numerical aperture water immersion lens. The microscope was attached to a confocal laser-scanning unit (Zeiss LSM 510). Fluo-4 fluorescence was probed every second by illumination with 488 -nm laser light and emission was detected between 500 and $550 \mathrm{~nm}$. The diameter of the pinhole was set to its maximum for all measurements. Images were taken in frame-mode at a pixel density of $512 \times 512$. Fluorescence signals were digitized at 8-bit resolution and analyzed using Metamorph software (Molecular Probes, Sunnyvale, CA). To quantitate amplitude and time course of changes in cytosolic fluo-4 fluorescence, i.e., $\mathrm{Ca}^{2+}$, signal intensities of pixels located inside the neuron soma (excluding the nuclei) were measured, spatially averaged, and background corrected $[\mathrm{F}(\mathrm{t})]$. Background fluorescence was measured as the average of a $40 \mathrm{x} 40$ pixel cellfree area outside the neuron soma of interest in each frame of every time series. Baseline fluorescence intensity $\left(\mathrm{F}_{0}\right)$ was determined by averaging $\mathrm{F}$ over the 10-s interval preceding the cell's exposure to elevated $\left[\mathrm{K}^{+}\right]$in the extracellular medium $\left(\left[\mathrm{K}^{+}\right]_{\mathrm{e}}\right)$, and the time course of normalized fractional dye fluorescence $\left[\Delta \mathrm{F} / \mathrm{F}_{0}(\mathrm{t})\right]$ was obtained, where $\Delta \mathrm{F}$ equals $\mathrm{F}(\mathrm{t})-\mathrm{F}_{0}$. Signal correction for bleaching was not necessary.

Cells were exposed to a high $\left[\mathrm{K}^{+}\right]$solution $(40,60,80$ or $100 \mathrm{mM} \mathrm{KCl})$ in the presence of $2 \mathrm{mM} \mathrm{Ca}^{2+}$ for $30 \mathrm{~s}$, followed by a 1-min exposure to normal Tyrode's solution. A second 30-s exposure to the same $\left[\mathrm{K}^{+}\right]_{\mathrm{e}}$ in the absence of extracellular $\mathrm{Ca}^{2+}$ (with $200 \mu \mathrm{M}$ EGTA added to the extracellular solution) was applied, and then the high $\left[\mathrm{K}^{+}\right]_{\mathrm{e}}$ solution was replaced with $\mathrm{Ca}^{2+}$-free normal Tyrode's solution. The first and second applications of high $\left[\mathrm{K}^{+}\right]_{\mathrm{e}}$ were separated by 3-min exposures to $\mathrm{Ca}^{2+}$-free normal Tyrode's solution. Bath solution exchanges were performed via manual injections ( $\sim 500 \mu \mathrm{l} / \mathrm{s})$ through the input port of the perfusion chamber. For each consecutive bath fluid exchange in the experimental protocol, the injected volume was $7 \mathrm{ml}$, corresponding to $\sim 27$ times the chamber volume. Solution changes were rapid, based on the fast and steady change in membrane potential achieved when cells were exposed to external solutions with elevated $\left[\mathrm{K}^{+}\right]$(see Fig $1 \mathrm{C}$ ). Nominally $\mathrm{Ca}^{2+}$-free Tyrode's solution contained the following (in $\mathrm{mM}$ ): $140 \mathrm{NaCl}, 5 \mathrm{KCl}, 1 \mathrm{MgCl}_{2}, 0.2 \mathrm{EGTA}, 10 \mathrm{HEPES}$, and $10 \mathrm{D}$-glucose ( $\mathrm{pH}$ 7.4). Assuming a $50 \mu \mathrm{M}$ total contaminating $\mathrm{Ca}^{2+}$, the free $\left[\mathrm{Ca}^{2+}\right]_{\mathrm{e}}$ was estimated to be $\sim 43 \mathrm{nM}[14,15]$. For $\mathrm{Ca}^{2+}$-containing Tyrode's solution, calcium was added $(2 \mathrm{mM})$ and EGTA was omitted. When stimulating with elevated $\left[\mathrm{K}^{+}\right]_{\mathrm{e}}, \mathrm{Na}^{+}$was adjusted to maintain osmolarity $[10,16]$. Where indicated, drugs were added $20 \mathrm{~min}$ before and included throughout the stimulation. Pilot experiments demonstrated that the magnitude of the high $\left[\mathrm{K}^{+}\right]_{\mathrm{e}}$-elicited $\mathrm{Ca}^{2+}$ response in $\mathrm{Ca}^{2+}$-free bath solution gradually decreased with consecutive $\left[\mathrm{K}^{+}\right]_{\mathrm{e}}$ tests. Therefore, the response to one tandem only of high $\left[\mathrm{K}^{+}\right]_{\mathrm{e}}$ exposure (in 2 and $0 \mathrm{mM}\left[\mathrm{Ca}^{2+}\right]_{\mathrm{e}}$ ) was tested in an individual neuron.

\section{Electrophysiology}

Whole-cell voltage- and current-clamp recordings were performed at room temperature using a Multiclamp 700B patch-clamp amplifier (Molecular Devices, Sunnyvale, CA, USA). Patch 


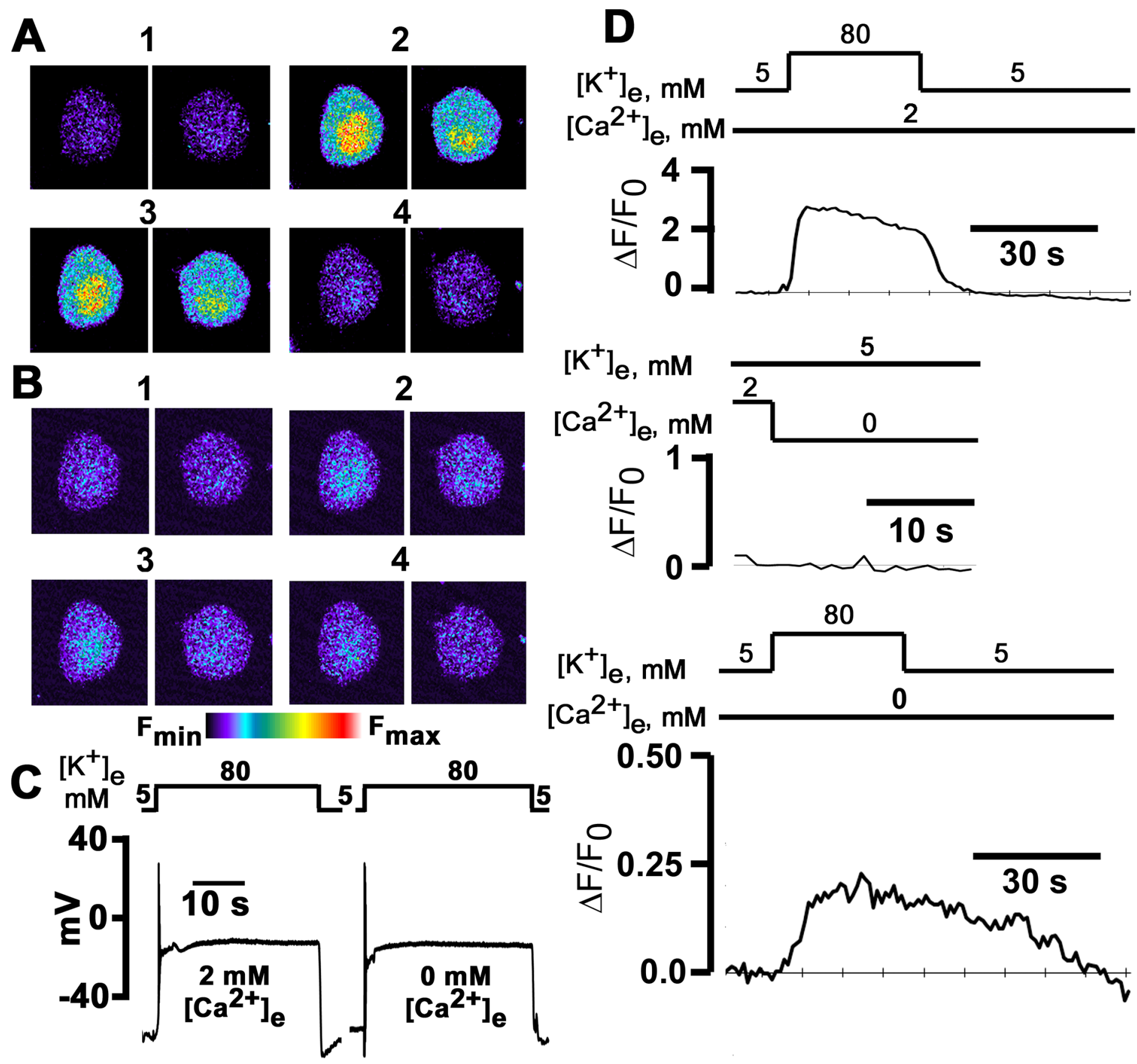

Fig 1. High $\left[\mathrm{K}^{+}\right]_{\mathrm{e}}$-induced intracellular $\mathrm{Ca}^{2+}$ transients in the presence and absence of extracellular $\mathrm{Ca}^{2+}$. A and $\mathrm{B}: x-y$ fluorescence images recorded in $24 \mathrm{~h}$ cultured sympathetic ganglion neurons loaded with fluo-4/AM before, during and following $30-\mathrm{s}$ depolarizations with $80 \mathrm{mM}\left[\mathrm{K}^{+}\right]_{\mathrm{e}}$ in $2 \mathrm{mM}\left[\mathrm{Ca}^{2+}\right]_{\mathrm{e}}(\mathbf{A})$

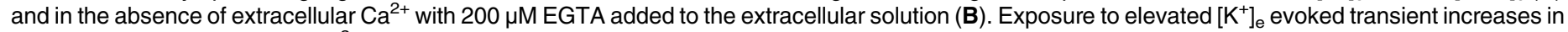
both cyto- and nucleoplasmic $\mathrm{Ca}^{2+}$ concentrations. Images in panels 2 and 3 were acquired at 10 and $30 \mathrm{~s}$ after initiating the $\left[\mathrm{K}^{+}\right]_{\mathrm{e}}$ challenge. $\mathrm{C}$ : High $\left[\mathrm{K}^{+}\right]_{\mathrm{e}}$ depolarizes the membrane potential both in the presence and absence of external $\mathrm{Ca}^{2+}: 80 \mathrm{mM}\left[\mathrm{K}^{+}\right]_{\mathrm{e}}$ rapidly depolarized $\mathrm{V}_{\mathrm{m}}$ from a resting membrane potential of $-44 \mathrm{mV}$ to $1 \mathrm{mV}$ in $2 \mathrm{mM}\left[\mathrm{Ca}^{2+}\right]_{e}$, and from $-41 \mathrm{mV}$ to $0 \mathrm{mV}$ in the absence of extracellular $\mathrm{Ca}^{2+}$. The level of depolarization was sustained for the duration of the $\left[\mathrm{K}^{+}\right]_{\mathrm{e}}$ challenge, both in the presence and absence of external $\mathrm{Ca}^{2+}$. D: Time courses of fractional fluorescence $\left(\Delta \mathrm{F} / \mathrm{F}_{0}\right)$, i.e., $\left[\mathrm{Ca}^{2+}\right]_{\mathrm{i}}$, in the cytoplasm during exposure to $80 \mathrm{mM}\left[\mathrm{K}^{+}\right]_{\mathrm{e}}$ in the presence and absence of external $\mathrm{Ca}^{2+} . \Delta \mathrm{F} / \mathrm{F}_{0}$ was calculated from the fluorescence intensity measured in the whole cytoplasm for each image taken every second.

doi:10.1371/journal.pone.0148962.g001 
pipettes were pulled in a model P-97 puller (Sutter Instruments, Novato, CA, USA) from borosilicate glass capillaries and heat-polished prior to use with a Narishige MF- 83 microforge (Narishige Inc., East Meadow, NY, USA). When filled with internal solution, the pipette resistance ranged from 2 to $5 \mathrm{M} \Omega$. During the recording, changes in the bath solution were made by gravity driven perfusion. Pipette capacitance was zeroed on sealing. Whole-cell capacitive transients were compensated by $60-80 \%$. Residual linear capacitive and leak currents were subtracted by the- $P / 6$ method. Currents and voltages were low-pass filtered at $1 \mathrm{kHz}$ and $5 \mathrm{kHz}$, respectively, using the built-in four-pole Bessel filter and sampled at 5 and $25 \mathrm{kHz}$, using a Digidata 1440A, acquired using Clampex10 and analyzed with Clampfit10 (all from Molecular Devices). Data collection was started $\sim 2$ to 3 min following membrane breakthrough.

Pipette solution for measuring whole-cell $\mathrm{Ca}^{2+}$ currents contained (in mM) 120 Cs-Aspartate, $1 \mathrm{MgCl}_{2}, 4 \mathrm{MgATP}, 0.3 \mathrm{Na}_{2} \mathrm{GTP}, 10$ EGTA and $10 \mathrm{HEPES}$ ( $\mathrm{pH}$ 7.2), whereas the bath solution was composed of (in mM) 140 TEA-Cl, $2 \mathrm{MgCl}_{2}, 2 \mathrm{CaCl}_{2}, 10$ glucose and 10 HEPES ( $\mathrm{pH}$ 7.4). For measuring ion currents through voltage-gate $\mathrm{Ca}^{2+}$ channels in the absence of extracellular $\mathrm{Ca}^{2+}$, the bath solution contained (in $\mathrm{mM}$ ) $140 \mathrm{NaCl}, 2 \mathrm{MgCl}_{2}, 0.2 \mathrm{EGTA}, 10$ glucose and 10 HEPES ( $\mathrm{pH}$ 7.4). For measuring action potentials, the pipette solution contained (in mM) $145 \mathrm{~K}$-Aspartate, $2 \mathrm{MgCl}_{2}, 5$ HEPES, $5 \mathrm{Na}_{2} \mathrm{ATP}$ and 1.1 EGTA (pH 7.2), and the bath solution consisted of (in $\mathrm{mM}$ ) $140 \mathrm{NaCl}, 5 \mathrm{KCl}, 1 \mathrm{MgCl}_{2}, 2 \mathrm{CaCl}_{2}, 10 \mathrm{HEPES}$ and 10 glucose ( $\mathrm{pH}$ 7.4). For $\mathrm{Ca}^{2+}$-free bath solutions, calcium was omitted and EGTA $(0.2 \mathrm{mM})$ was added. When recording the effects of elevating $\left[\mathrm{K}^{+}\right]_{\mathrm{e}}$ on membrane potential, $\left[\mathrm{Na}^{+}\right]$was lowered to maintain osmolarity. Osmolarities of all bath and pipette solutions were adjusted to 310 and $315 \mathrm{mOsm}$, respectively, using mannitol. Membrane potentials were adjusted for liquid junction potentials unless stated otherwise.

To characterize voltage dependence of peak $I_{\mathrm{Ca}}$ and to determine the $I_{\mathrm{Ca}}$ activation curve, currents were evoked by 300 -ms pulses ranging from -90 to $+60 \mathrm{mV}$ in steps of $5 \mathrm{mV}$. The interval between voltage steps was $10 \mathrm{~s}$. The peak $I_{\text {Ca.L }}$ density at each potential was plotted as a function of test voltage to generate the $I-V$ curves. Activation curves were fitted with the following Boltzmann distribution equation: $\left.G / G_{\max }=1 /\left\{1+\exp \left[V_{1 / 2}-V\right) / k\right]\right\}$, where $G$ is the voltage-dependent calcium conductance, $G_{\max }$ is the maximal calcium conductance, $V_{1 / 2}$ is the potential at which activation is half-maximal, $V$ is the membrane potential, and $k$ is the slope. $G$ values were determined by the following equation: $G=I_{\max } /\left(V-E_{C a}\right)$, where $E_{C a}$ is the reversal potential.

To examine steady-state inactivation, the voltage that gave maximal peak current was used for subsequent protocols. Cells were administered a series of prepulses (-90 to $40 \mathrm{mV}$ ) lasting $300 \mathrm{~ms}$, from a holding potential of $-90 \mathrm{mV}$, followed, after a $20-\mathrm{ms}$ gap at $-90 \mathrm{mV}$, by a 300 -ms depolarization to a voltage eliciting the maximal peak current $(0 \mathrm{mV})$. The interval between conditioning prepulses was $10 \mathrm{~s}$. The resulting curves were normalized and fitted using the following Boltzmann distribution equation: $I / I_{\max }=1 /\left\{1+\exp \left[\left(V-V_{1 / 2}\right) / k\right]\right\}+C$, where $I_{\max }$ is the peak current elicited after the most hyperpolarized prepulse, $V$ is the preconditioning pulse potential, and $C$ is a constant.

The membrane capacitance was calculated from $5-\mathrm{mV}$ hyperpolarizing and depolarizing steps (20 ms) applied from a folding potential of $-70 \mathrm{mV}$ according to the equation: $C_{M}=\tau /$ $\Delta V^{*} I_{0} /\left(1-I_{\infty} / I_{0}\right)$, where $C_{M}$ is membrane capacitance, $\tau$ is the time constant of the capacitance current relaxation, $I_{0}$ is the peak capacitive current determined by single exponential fit and extrapolation to the first sample point after the voltage step $\Delta V$, and $I_{\infty}$ is the amplitude of the steady-state current during the voltage step [17]. Capacitive currents were sampled at 25 $\mathrm{kHz}$ and filtered at $5 \mathrm{kHz}$. 


\section{Data analysis}

Summarized data are expressed as means \pm SEM. Statistical analyses were determined by paired $t$-test, unpaired $t$-test, and parametric and non-parametric one-way analyses of variance coupled with the appropriate post hoc analyses to determine significance $(P<0.05)$. Fisher Exact test was used to determine differences of proportions.

\section{Chemicals}

Stock solutions of 2-aminoethoxydiphenyl borate (2-APB), nifedipine, ryanodine and thapsigargin were prepared in DMSO. The final DMSO concentration in the experimental solution did not exceed $1 \mu \mathrm{l} / \mathrm{ml}$. Caffeine stock solution was prepared in $\mathrm{ddH}_{2} \mathrm{O}$. Stock solution of tetrakis (2-pyridylmethyl) ethylendiamine (TPEN) was prepared in ethanol, and xestospongin C stock solution was made in PBS.

\section{Results}

\section{High $\left[\mathrm{K}^{+}\right]_{\mathrm{e}}$-induced membrane depolarization evokes $\mathrm{Ca}^{2+}$ transients in mouse sympathetic ganglion neurons in the absence of extracellular $\mathrm{Ca}^{2+}$}

Raising extracellular $\left[\mathrm{K}^{+}\right]$has been previously shown by others to produce stable and reproducible membrane depolarization in sympathetic ganglion neurons in culture, increasing intracellular free $\left[\mathrm{Ca}^{2+}\right]$ in the presence of external $\mathrm{Ca}^{2+}[10]$. Here, we combined $\left[\mathrm{K}^{+}\right]_{\mathrm{e}}$ depolarization with fluorescent $\mathrm{Ca}^{2+}$ imaging to examine the possibility that membrane depolarization evokes $\mathrm{Ca}^{2+}$ transients within isolated sympathetic ganglion neurons of adult mice not only in the presence of extracellular $\mathrm{Ca}^{2+}$ but also in its absence. Representative $\mathrm{Ca}^{2+}$ responses of two fluo-4/AM-loaded neurons elicited by consecutive 30 -s exposures to $80 \mathrm{mM}\left[\mathrm{K}^{+}\right]_{\mathrm{e}}$ in the presence of $2 \mathrm{mM}\left[\mathrm{Ca}^{2+}\right]_{e}$ and in $\mathrm{Ca}^{2+}$-free bath solution (with $200 \mu \mathrm{M}$ EGTA added) are illustrated in Fig $1 \mathrm{~A}$ and $1 \mathrm{~B}$, respectively. Elevating $\left[\mathrm{K}^{+}\right]_{\mathrm{e}}$ in normal $\mathrm{Ca}^{2+}$ gave rise to increases in global fluorescence intensity, which were larger in the nuclei than in the cytosols (Fig 1A). The fluorescence signals remained elevated throughout the exposure to high $\left[\mathrm{K}^{+}\right]_{\mathrm{e}}$ (panels 2 and 3 in Fig $1 \mathrm{~A}$ ) and returned to baseline values following restoration of $\left[\mathrm{K}^{+}\right]_{\mathrm{e}}$ (panel 4 in Fig $1 \mathrm{~A}$ ). The $\left[\mathrm{K}^{+}\right]_{\mathrm{e}}$ challenge was repeated in the absence of extracellular $\mathrm{Ca}^{2+}$ following a 3-min exposure to $\mathrm{Ca}^{2+}$-free normal Tyrode's solution. As illustrated in Fig $1 \mathrm{~B}$, a second 30-s exposure to $80 \mathrm{mM}$ $\left[\mathrm{K}^{+}\right]$in the absence of external $\mathrm{Ca}^{2+}$ gave rise to sustained elevations in intracellular $\mathrm{Ca}^{2+}$ (panels 2 and 3 in Fig 1B), although the magnitude of the effect was markedly reduced compared to the $2 \mathrm{mM}\left[\mathrm{Ca}^{2+}\right]_{\mathrm{e}}$ condition. Fluorescence signal intensity recovered upon restoration of $\left[\mathrm{K}^{+}\right]_{\mathrm{e}}$ in the continued absence of extracellular $\mathrm{Ca}^{2+}$.

To make certain that membrane depolarization evoked by $80 \mathrm{mM}\left[\mathrm{K}^{+}\right]_{\mathrm{e}}$ was maintained at similar potentials in the presence and absence of external $\mathrm{Ca}^{2+}$, the membrane potential was recorded from isolated sympathetic neurons before and during the 30-s depolarization. A representative example is shown in Fig 1C. Both in the presence and absence of extracellular $\mathrm{Ca}^{2+}$, high $\left[\mathrm{K}^{+}\right]_{\mathrm{e}}$ rapidly depolarized the neuron following the solution change, and remained stable while $\left[\mathrm{K}^{+}\right]_{\mathrm{e}}=80 \mathrm{mM}$. The magnitude of depolarization appeared similar under both conditions. After $\left[\mathrm{K}^{+}\right]_{\mathrm{e}}$ was restored to $5 \mathrm{mM}$, membrane potential exhibited a transient afterhyperpolarization in $2 \mathrm{mM}\left[\mathrm{Ca}^{2+}\right]_{\mathrm{e}}$. On average, the degree of membrane depolarization evoked by $80 \mathrm{mM}\left[\mathrm{K}^{+}\right]_{\mathrm{e}}$ in $0 \mathrm{mM}\left[\mathrm{Ca}^{2+}\right]_{\mathrm{e}}$ was slightly less than that in $2 \mathrm{mM}\left[\mathrm{Ca}^{2+}\right]_{\mathrm{e}}$ (see Table 1 ).

Next, we sought to quantitate the high $\left[\mathrm{K}^{+}\right]_{\mathrm{e}}$-evoked changes in cytosolic $\mathrm{Ca}^{2+}$ level, using $\Delta \mathrm{F} / \mathrm{F}_{0}$ as a measure. Plots of $\Delta \mathrm{F} / \mathrm{F}_{0}$ as a function of time for one of the neurons in Fig $1 \mathrm{~A}$ and $1 \mathrm{~B}$ are displayed in Fig 1D. The neuron responds to high $\left[\mathrm{K}^{+}\right]_{\mathrm{e}}$ exposure with an initial peak 
Table 1. Membrane potentials of sympathetic ganglion neurons at rest and during depolarization with elevated $\left[\mathrm{K}^{+}\right]_{\mathrm{e}}$ in normal $\left[\mathrm{Ca}^{2+}\right]_{\mathrm{e}}$ and in the absence of extracellular $\mathrm{Ca}^{2+}$ (with $200 \mu \mathrm{M} \mathrm{EGTA}$ added to the bath solution). Values are expressed as means \pm SEM.

\begin{tabular}{|c|c|c|}
\hline$\left[\mathrm{K}^{+}\right]_{\mathrm{e}}, \mathrm{mM}$ & $2 \mathrm{mM}\left[\mathrm{Ca}^{2+}\right]_{\mathrm{e}}, \mathrm{mV}$ & $0 \mathrm{mM}\left[\mathrm{Ca}^{2+}\right]_{\mathrm{e}}, \mathrm{mV}$ \\
\hline 5 & $-61.8 \pm 4.4$ & $-59.9 \pm 3.1$ \\
\hline 40 & $-31.8 \pm 1.4$ & $-31.2 \pm 0.7$ \\
\hline 60 & $-21.9 \pm 0.9$ & $-23.2 \pm 0.9$ \\
\hline 80 & $-15.7 \pm 0.5$ & $-18.5 \pm 0.8^{*}$ \\
\hline 100 & $-11.5 \pm 0.6$ & $-14.2 \pm 0.8^{*}$ \\
\hline
\end{tabular}

${ }^{*} P<0.05$ versus $2 \mathrm{mM}\left[\mathrm{Ca}^{2+}\right]_{\mathrm{e}}$ by paired $t$-test or Wilcoxon Signed Rank test.

doi:10.1371/journal.pone.0148962.t001

followed by a slow, spontaneous decay, which was seen in all cells tested, despite the fact that the depolarization of the plasma membrane was maintained throughout the $30-\mathrm{s}\left[\mathrm{K}^{+}\right]_{\mathrm{e}}$ challenge. Increases in $\Delta \mathrm{F} / \mathrm{F}_{0}$ typically resolved within less than $15 \mathrm{~s}$ after restoration of $\left[\mathrm{K}^{+}\right]_{\mathrm{e}}$. Replacement of normal Tyrode's solution with $\mathrm{Ca}^{2+}$-free solution did not evoke significant changes in cytosolic $\left[\mathrm{Ca}^{2+}\right]$ (Fig 1D, middle panel), indicating that the solution change per se does not contribute to the rise in fluo-4 fluorescence seen in response to elevated $\left[\mathrm{K}^{+}\right]_{\mathrm{e}}$ in the absence of external $\mathrm{Ca}^{2+}$. A 30-s exposure of the same neuron to $80 \mathrm{mM}\left[\mathrm{K}^{+}\right]_{\mathrm{e}}$ in $\mathrm{Ca}^{2+}$-free bath solution evoked a low-amplitude $\mathrm{Ca}^{2+}$ transient which exhibited markedly slower rise and decay kinetics compared to the transient in $2 \mathrm{mM}\left[\mathrm{Ca}^{2+}\right]_{\mathrm{e}}$ (Fig 1D, lower panel). Overall, 47 (78\%) of a total of 60 neurons responded with a rise in cytosolic $\left[\mathrm{Ca}^{2+}\right]$ in the absence of extracellular $\mathrm{Ca}^{2+}$. To assess whether loss of cellular viability gives rise to these marked differences in $\mathrm{Ca}^{2+}$ transient properties, a subset of neurons were re-exposed to high $\left[\mathrm{K}^{+}\right]_{\mathrm{e}}$ in normal $\left[\mathrm{Ca}^{2+}\right]_{\mathrm{e}}$ following the $\left[\mathrm{K}^{+}\right]_{\mathrm{e}}$ test in $\mathrm{Ca}^{2+}$ free conditions. A representative $\Delta \mathrm{F} / \mathrm{F}_{0}(\mathrm{t})$ tracing is shown in Fig 2A. After raising $\left[\mathrm{Ca}^{2+}\right]_{\mathrm{e}}$ to $2 \mathrm{mM}$, the peak amplitude of the high $\left[\mathrm{K}^{+}\right]_{\mathrm{e}}$-evoked $\mathrm{Ca}^{2+}$ transient clearly exceeded that of the preceding transient recorded in the absence of external $\mathrm{Ca}^{2+}$, and its time course was indistinguishable from that of a response typically seen during initial exposures to high $\left[\mathrm{K}^{+}\right]_{\mathrm{e}}$ in $2 \mathrm{mM}\left[\mathrm{Ca}^{2+}\right]_{\mathrm{e}}$. Identical observations were made in 7 cells. These results prove that the neurons remain viable and support the notion that the differences in $\mathrm{Ca}^{2+}$ transient properties between 2 and $0 \mathrm{mM}\left[\mathrm{Ca}^{2+}\right]_{\mathrm{e}}$ are unlikely to result from unspecific effects of the exposure to the $\mathrm{Ca}^{2+}$ free bath solution. At $80 \mathrm{mM}\left[\mathrm{K}^{+}\right]_{e}$, the average peak $\mathrm{Ca}^{2+}$ transient amplitude was markedly smaller in the absence than in the presence of external $\mathrm{Ca}^{2+}$ and their average rise and decay times were markedly prolonged compared to $\mathrm{Ca}^{2+}$ transients evoked in normal $\left[\mathrm{Ca}^{2+}\right]_{\mathrm{e}}$ (Fig 2B). Overall, these results suggest that a subpopulation of sympathetic neurons possess the ability to release $\mathrm{Ca}^{2+}$ from intracellular stores in response to prolonged membrane depolarization in the absence of extracellular $\mathrm{Ca}^{2+}$.

To relate the magnitude of the $\mathrm{Ca}^{2+}$ responses to membrane depolarization, we next recorded $\mathrm{Ca}^{2+}$ transients during exposure to various $\mathrm{K}^{+}$concentrations. In a parallel series of experiments, we measured membrane voltage in isolated neurons, using external solutions identical to those in the $\mathrm{Ca}^{2+}$ imaging experiments.

Exposure to $40,60,80$ and $100 \mathrm{mM}\left[\mathrm{K}^{+}\right]_{\mathrm{e}}$ in $2 \mathrm{mM}\left[\mathrm{Ca}^{2+}\right]_{\mathrm{e}}$ caused progressively increasing membrane depolarizations (Table 1), yielding a slope of $67.5 \mathrm{mV}$ per 10 -fold change in $\left[\mathrm{K}^{+}\right]_{\mathrm{e}}$ (solid line in Fig 2C). Plotting the magnitude of peak $\Delta \mathrm{F} / \mathrm{F}_{0}$ transient amplitude against membrane potential (Fig 2D) revealed a linear increase over a range between -31.8 and $-11.5 \mathrm{mV}$. Removal of $\mathrm{Ca}^{2+}$ from the extracellular solution did not significantly alter the resting membrane potential in $5 \mathrm{mM}\left[\mathrm{K}^{+}\right]$Tyrode's solution (Table 1). Progressive elevations in $\left[\mathrm{K}^{+}\right]_{\mathrm{e}}$ caused depolarizations that were of similar magnitude to those seen in $2 \mathrm{mM}\left[\mathrm{Ca}^{2+}\right]_{\mathrm{e}}$ (Table 1), 

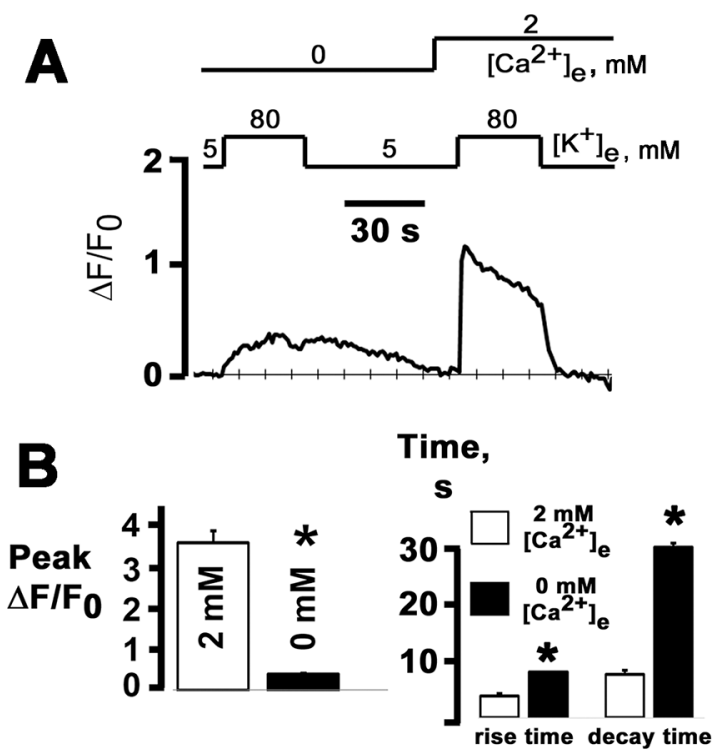

D

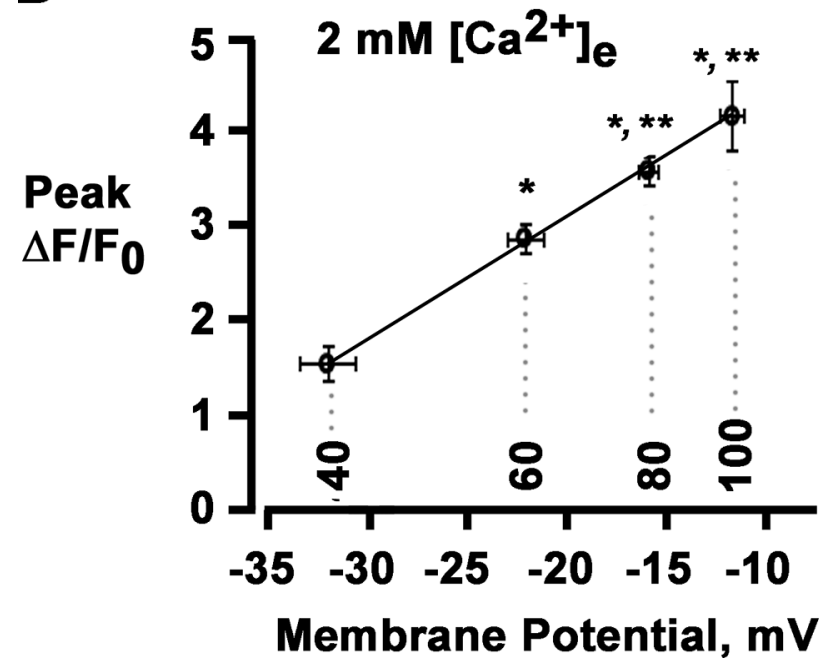

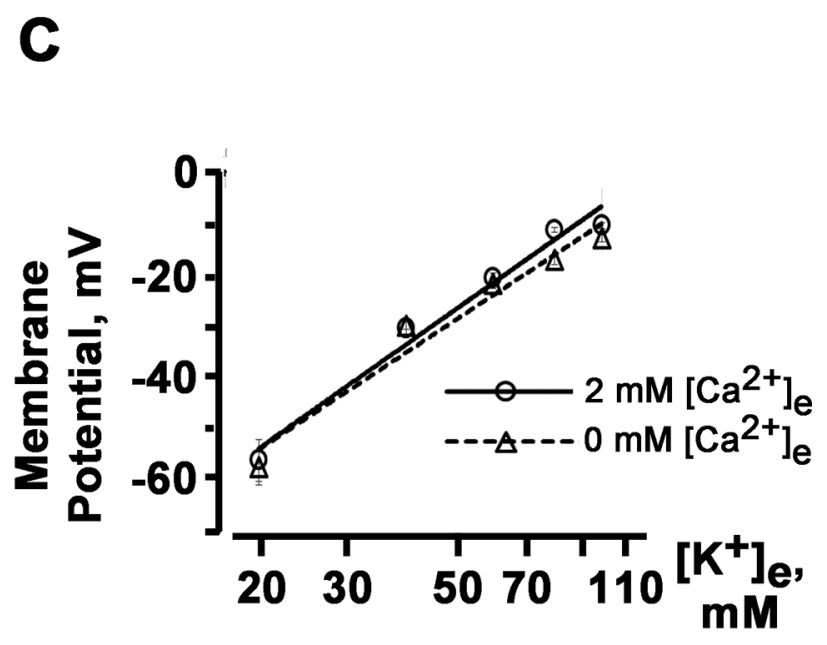

$\mathbf{E}$

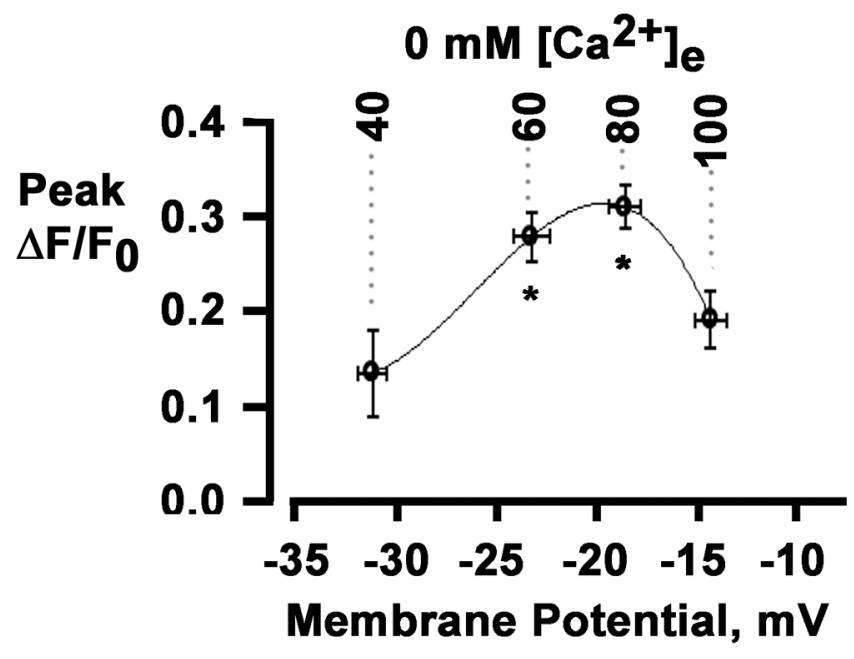

Fig 2. Sympathetic neurons possess the ability to release $\mathrm{Ca}^{2+}$ from intracellular stores in response to prolonged membrane depolarization in the absence of extracellular $\mathrm{Ca}^{2+}$. A: Time course of cytosolic fluo- $4 \Delta \mathrm{F} / \mathrm{F}_{0}$ in a sympathetic neuron in response to a $30-\mathrm{s}$ exposure to $80 \mathrm{mM}\left[\mathrm{K}^{+}\right]_{\mathrm{e}}$ in $2 \mathrm{mM}$ $\left[\mathrm{Ca}^{2+}\right]_{e}$ and a 30 -s exposure to $80 \mathrm{mM}\left[\mathrm{K}^{+}\right]_{\mathrm{e}}$ in $\mathrm{Ca}^{2+}$-free solution, followed by a second 30 -s application of $80 \mathrm{mM}\left[\mathrm{K}^{+}\right]_{e}$ in $2 \mathrm{mM}\left[\mathrm{Ca}^{2+}\right]_{e}$ applied 70 seconds after the $\mathrm{Ca}^{2+}$ transient was elicited in $\mathrm{Ca}^{2+}$ - free solution. $\mathrm{B}$ : Bar graphs of peak magnitude of the cytosolic $\Delta \mathrm{F} / \mathrm{F}_{0}$ transients (left panel) and their rise and decay times during exposure to $80 \mathrm{mM}\left[\mathrm{K}^{+}\right]_{\mathrm{e}}$ in the presence and absence of extracellular $\mathrm{Ca}^{2+}$ (with $200 \mu \mathrm{M} \mathrm{EGTA}$ added). Rise times and decay times were measured as the intervals from $10 \%$ to $90 \%$ and from $90 \%$ to $10 \%$, respectively, of peak $\Delta F / F_{0}$. Values are mean \pm SEM from 48 to 87 cells. ${ }^{*} P<0.0001$ versus $2 \mathrm{mM}\left[\mathrm{Ca}^{2+}\right]_{\mathrm{e}}$, paired $t$-test. C: Plots of sympathetic neuron membrane potential as a function of $\left[\mathrm{K}^{+}\right]_{\mathrm{e}}$. Values are mean $\pm \mathrm{SEM}(\mathrm{n}=5-8$ experiments for each $\left[\mathrm{K}^{+}\right]_{\mathrm{e}}$ studied). Lines are linear fits with slopes of $67.5 \mathrm{mV}\left(2 \mathrm{mM}\left[\mathrm{Ca}^{2+}\right]_{\mathrm{e}}\right)$ and $62.2 \mathrm{mV}\left(0 \mathrm{mM}\left[\mathrm{Ca}^{2+}\right]_{\mathrm{e}}\right)$ per 10 -fold change in $\left[\mathrm{K}^{+}\right]_{\mathrm{e}}$. D and E: Peak magnitude of cytosolic $\Delta \mathrm{F} / \mathrm{F}_{0}$ transients as a function of membrane potential. Shown are the relationships between membrane potential and peak $\Delta \mathrm{F} / \mathrm{F}_{0}$ amplitude in response to 30 -s exposures to $40,60,80$ or $100 \mathrm{mM}\left[\mathrm{K}^{+}\right]_{\mathrm{e}}$ in $2 \mathrm{mM}\left[\mathrm{Ca}^{2+}\right]_{e}$ (D) or in the absence of extracellular Ca ${ }^{2+}(E)$. Values are mean \pm SEM $\left(n=18-87\right.$ cells for each $\left.\left[K^{+}\right]_{e}\right)$. Solid lines represent best fits of the data to a linear function (D) and a polynomial function (E). Dashed lines denote membrane potentials generated by each $\left[\mathrm{K}^{+}\right]_{\mathrm{e}}$. B: ${ }^{*} P<0.001$ versus $40 \mathrm{mM}\left[\mathrm{K}^{+}\right]_{\mathrm{e}} ;{ }^{*} P<0.03$ versus $60 \mathrm{mM}\left[\mathrm{K}^{+}\right]_{\mathrm{e}}$. C: ${ }^{*} P<0.05$ versus $40 \mathrm{mM}\left[\mathrm{K}^{+}\right]_{\mathrm{e}}$; repeated measures ANOVA and Dunn's method for multiple comparisons.

doi:10.1371/journal.pone.0148962.g002

giving rise to a slope of $62.2 \mathrm{mV}$ per 10 -fold change in $\left[\mathrm{K}^{+}\right]_{\mathrm{e}}$ (dashed line in Fig $2 \mathrm{C}$ ). Over the voltage range examined ( -31.2 to $-14.2 \mathrm{mV})$, the magnitude of peak $\Delta \mathrm{F} / \mathrm{F}_{0}$ transient amplitude displayed an inverse $U$-shaped dependence on membrane potential as shown in Fig $2 \mathrm{E}$, which is in sharp contrast to the linear rise in peak $\Delta \mathrm{F} / \mathrm{F}_{0}$ amplitude that was observed in response to progressively increasing membrane depolarizations in $2 \mathrm{mM}\left[\mathrm{Ca}^{2+}\right]_{\mathrm{e}}$ (Fig 2D). 
The increase in the magnitude of $\mathrm{Ca}^{2+}$ transient amplitude with increasing depolarization in the presence of $2 \mathrm{mM}$ extracellular $\mathrm{Ca}^{2+}$ suggested a role of voltage-gated $\mathrm{Ca}^{2+}$ channel activity in governing this relationship, as had been described previously in mammalian postganglionic sympathetic neurons $[10,18]$. Accordingly, to relate $\mathrm{Ca}^{2+}$ transient properties to $\mathrm{Ca}^{2+}$ channel activity, we measured whole-cell $\mathrm{Ca}^{2+}$ currents $\left(I_{\mathrm{Ca}}\right)$ over a wide range of voltages including those generated by the lowest and highest $\left[\mathrm{K}^{+}\right]_{\mathrm{e}}$ used in the $\mathrm{Ca}^{2+}$ imaging experiments. Short depolarizations evoked $\mathrm{Ca}^{2+}$ currents exhibiting no, or very little, inactivation (Fig 3A). A plot of peak $I_{C a}$ as a function of voltage is shown in Fig 3B, exhibiting the typical bell-shaped dependence on membrane potential. The descending portion of the $I_{\mathrm{Ca}}-V$ curve largely coincided with the voltage range over which peak $\Delta \mathrm{F} / \mathrm{F}_{0}$ increased (see Fig $2 \mathrm{D}$ ), suggesting that the membrane potential dependence of peak $I_{\mathrm{Ca}}$ controls $\mathrm{Ca}^{2+}$ transient magnitude over the range of membrane depolarizations studied here. This observation is in agreement with previous studies $[10,18]$. To examine whether depolarization-induced changes in $\mathrm{Ca}^{2+}$ channel gating underlie the membrane potential-dependence of peak $\Delta \mathrm{F} / \mathrm{F}_{0}$ in the absence of external $\mathrm{Ca}^{2+}$, we next determined the voltage-dependence of $\mathrm{Ca}^{2+}$ channel activation. The result is shown in Fig 3C. The probability of the channel of being activated $\left(P_{\text {act }}\right)$ increased in a sigmoidal fashion as the membrane potential became more depolarized. This behavior contrasts with the inverse $U$ shaped dependence of peak $\Delta \mathrm{F} / \mathrm{F}_{0}$ on voltage in $\mathrm{Ca}^{2+}$-free bath solution (Fig $2 \mathrm{E}$ ), suggesting that membrane potential-dependent changes in peak $P_{\text {act }}$ of voltage-activated $\mathrm{Ca}^{2+}$ channels do not constitute the trigger for $\mathrm{Ca}^{2+}$ release in $0 \mathrm{mM}\left[\mathrm{Ca}^{2+}\right]_{\mathrm{e}}$.

The slow kinetics of increase in $\left[\mathrm{Ca}^{2+}\right]_{\mathrm{i}}$ during sustained membrane depolarization in the absence of external $\mathrm{Ca}^{2+}$ (see Fig 2B) suggested the possibility that $\mathrm{Ca}^{2+}$ release is regulated by the steady-state activity of voltage-gated $\mathrm{Ca}^{2+}$ channels. The steady-state probability of a channel of being activated is the product of peak $P_{\text {act }}$ (obtained from the activation curve in Fig 3C) and the probability of not being inactivated $\left(1-P_{\text {inact }}\right)$, i. e., steady-state $P_{\text {act }}=$ (peak $\left.P_{\text {act }}\right){ }^{*}\left(1-P_{\text {inact }}\right)$. Accordingly, we next determined the voltage-dependence of $I_{\mathrm{Ca}}$ inactivation. Channel inactivation displayed a U-shaped dependence on voltage (Fig 3D). Fits of the descending portion of the inactivation curve to a Boltzmann distribution revealed $V_{1 / 2}$ and $k$ values of $-55.3 \mathrm{mV}$ and $16.3 \mathrm{mV}$, respectively. Fig $3 \mathrm{E}$ shows the relationship between membrane potential and steady-state $P_{\text {act }}$. Negative to $-20 \mathrm{mV}$, steady-state $P_{\text {act }}$ increased steeply, whereas it decreased slightly at less negative potentials. Thus, steady-state activation of voltagegated $\mathrm{Ca}^{2+}$ channels and peak $\Delta \mathrm{F} / \mathrm{F}_{0}$ in the absence of external $\mathrm{Ca}^{2+}$ shared a similar, i.e., inverse $\mathrm{U}$-shaped, dependence on membrane potential over identical voltage ranges, suggesting that magnitudes of changes in the depolarization-induced $\left[\mathrm{Ca}^{2+}\right]_{\mathrm{i}}$ in $0 \mathrm{mM}\left[\mathrm{Ca}^{2+}\right]_{\mathrm{e}}$ are controlled by the steady-state gating of voltage-activated $\mathrm{Ca}^{2+}$ channels.

\section{Depolarization in $\mathrm{Ca}^{2+}$ free solution induces $\mathrm{Ca}^{2+}$ release from $\mathrm{IP}_{3^{-}}$, but not ryanodine-, sensitive internal stores}

To investigate the role of $\mathrm{Ca}^{2+}$ release from internal stores in mediating depolarization-induced increases in cytosolic $\left[\mathrm{Ca}^{2+}\right]$, we next assessed the effects of the $\mathrm{Ca}^{2+}$-ATPase inhibitor thapsigargin $(1 \mu \mathrm{M})$ on high $\left[\mathrm{K}^{+}\right]_{\mathrm{e}}$-evoked $\mathrm{Ca}^{2+}$ responses in isolated sympathetic neurons. Neurons were pre-incubated with thapsigargin for $20 \mathrm{~min}$ while being loaded with fluo-4/AM and then subjected to $\mathrm{Ca}^{2+}$ imaging in the continued presence of the inhibitor. Representative plots of $\Delta \mathrm{F} / \mathrm{F}_{0}$ as a function of time are shown in Fig 4 . A 30 -s exposure to $80 \mathrm{mM}\left[\mathrm{K}^{+}\right]_{\mathrm{e}}$ in the presence of extracellular $\mathrm{Ca}^{2+}$ caused an increase in cytosolic $\left[\mathrm{Ca}^{2+}\right]$. A second 30-s exposure to $80 \mathrm{mM}$ $\left[\mathrm{K}^{+}\right]$in the absence of external $\mathrm{Ca}^{2+}$ did not evoke a significant increase in intracellular $\left[\mathrm{Ca}^{2+}\right]$. Overall, only $2(10.5 \%)$ of 19 thapsigargin-treated neurons developed $\mathrm{Ca}^{2+}$ transients during exposure to elevated $\left[\mathrm{K}^{+}\right]_{\mathrm{e}}$ in the absence of extracellular $\mathrm{Ca}^{2+}$ compared to $47(78 \%)$ of 60 

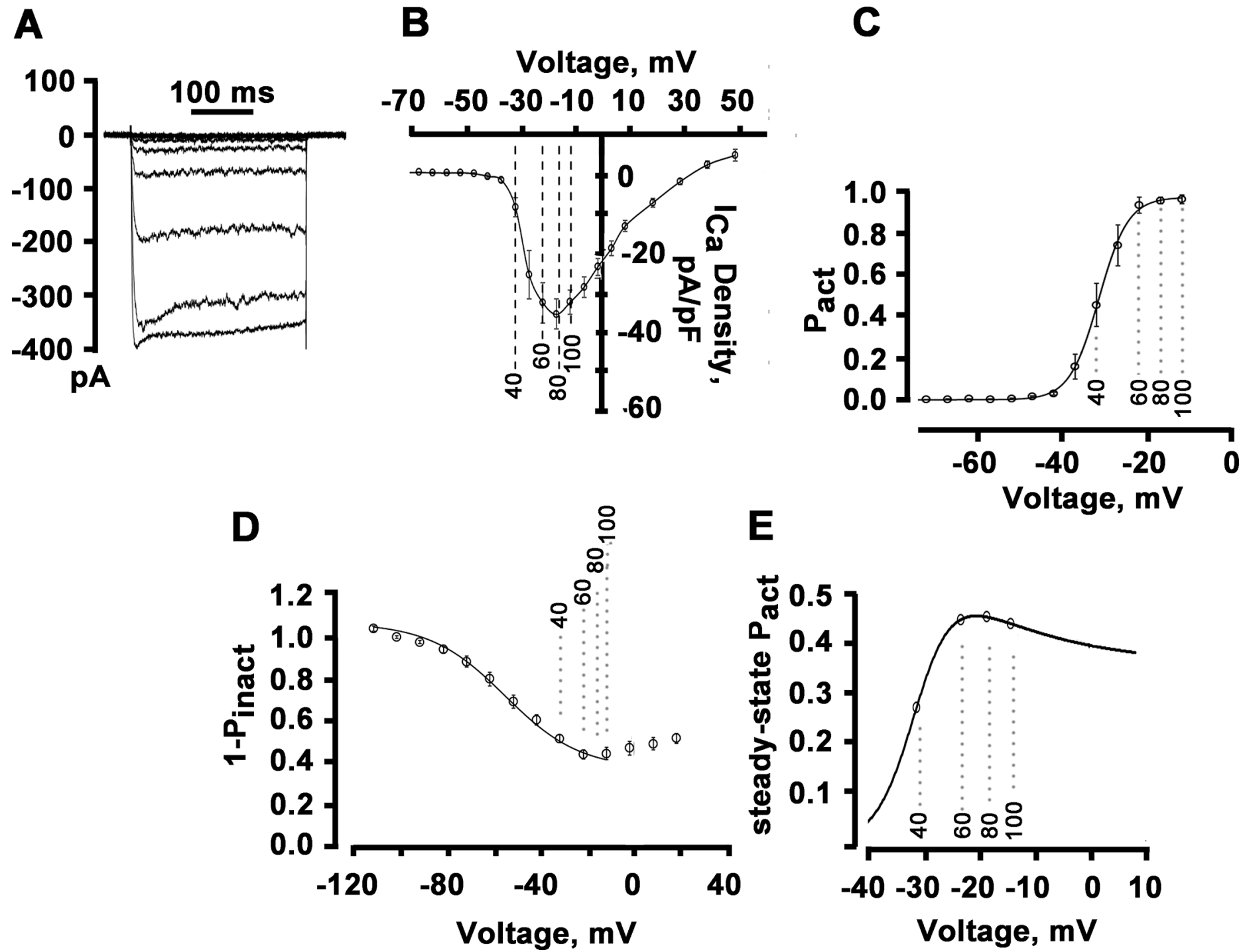

Fig 3. Peak magnitude of cytosolic $\Delta \mathrm{F} / \mathrm{F}_{\mathbf{0}}$ transients as a function of calcium channel activity. $A$ : Representative traces of whole-cell $I_{\mathrm{Ca}}$ recordings with $2 \mathrm{mM}\left[\mathrm{Ca}^{2+}\right]_{\mathrm{e}}$. Currents were elicited using $300-\mathrm{ms}$ depolarizations ranging between -50 and $+10 \mathrm{mV}$ in $5-\mathrm{mV}$ steps. Pulse interval was $10 \mathrm{~s}$. B: Peak $I_{\mathrm{Ca}}-$ voltage relationship. Current amplitudes were normalized to cell capacitance and plotted as mean values. Error bars represent $S E M(n=11$ cells). Dashed lines indicate voltages generated by each $\left[\mathrm{K}^{+}\right]_{\mathrm{e}}$ in $2-\mathrm{mM}\left[\mathrm{Ca}^{2+}\right]_{\mathrm{e}}$ bath solutions. C: Voltage-dependence of steady-state $I_{\mathrm{Ca}}$ activation, $P_{\text {act }}$. Values are mean \pm SEM for 11 cells. The solid line represents the mean of the best fit to each cell by a Boltzmann distribution, with $V_{1 / 2}$ and $k$ values of $-31.2 \mathrm{mV}$ and $3.4 \mathrm{mV}$, respectively. D: Voltage-dependence of steady-state $I_{\mathrm{Ca}}$ inactivation, $\left(1-P_{\text {inact }}\right)$. For measuring voltage-dependence of inactivation, a paired-pulse voltage protocol was used consisting of a 300-ms conditioning prepulse to voltages from -90 to $40 \mathrm{mV}$ followed, after a $20-\mathrm{ms}$ gap at $-90 \mathrm{mV}$, by a 300 -ms test pulse to $0 \mathrm{mV}$. Holding potential was $-90 \mathrm{mV}$ and the interval between conditioning prepulses as $10 \mathrm{~s}$. For generating inactivation curve, the peak amplitudes of currents evoked by the test pulse were normalized to the current evoked during each prepulse and plotted as a function of prepulse potential. Solid line is the mean of the best fit of the descending portion of the inactivation-voltage relationship (i.e., between -111.9 and $18.1 \mathrm{mV}$ ) to a Boltzmann function, with $V_{1 / 2}$ and $k$ values of $55.3 \mathrm{mV}$ and $16.3 \mathrm{mV}$, respectively. Values are mean $\pm \mathrm{SEM}\left(\mathrm{n}=8\right.$ cells). E: Calculated voltage-dependence of steady-state $P_{\text {act }}$ of high voltage-gated $\mathrm{Ca}^{2+}$ channels in sympathetic ganglion neurons. The curve shows the theoretical steady-state $P_{\text {act }}$ at any potential, using the Boltzmann values for the amount of available current and the amount of current inactivation. The maximum available current was set to 1 . Circles denote values for steady-state $P_{\text {act }}$ at voltages generated by each $\left[\mathrm{K}^{+}\right]_{\mathrm{e}}$ in $\mathrm{Ca}^{2+}$-free bath solutions.

doi:10.1371/journal.pone.0148962.g003

non-treated cells $(P<0.001$; Fig 4B). To make certain that membrane depolarization evoked by $80 \mathrm{mM}\left[\mathrm{K}^{+}\right]_{\mathrm{e}}$ was maintained at similar potentials among thapsigargin-treated and nontreated neurons in the study, we compared membrane potentials recorded from isolated sympathetic neurons before and during high $\left[\mathrm{K}^{+}\right]_{\mathrm{e}}$-induced depolarizations in the presence of the 
A

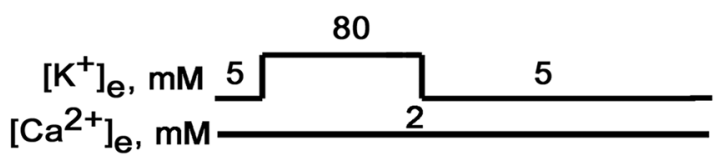

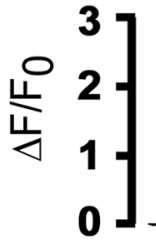

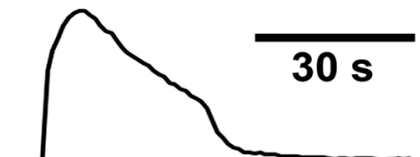

C

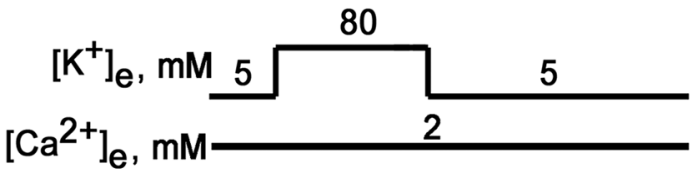

ryanodine

$\left.\begin{array}{l}1 \\ 0\end{array}\right]$

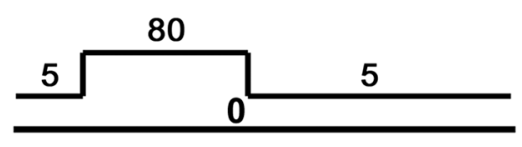$$
\left[\mathrm{Ca}^{2+}\right]_{\mathrm{e}}, \mathrm{mM} \longrightarrow
$$
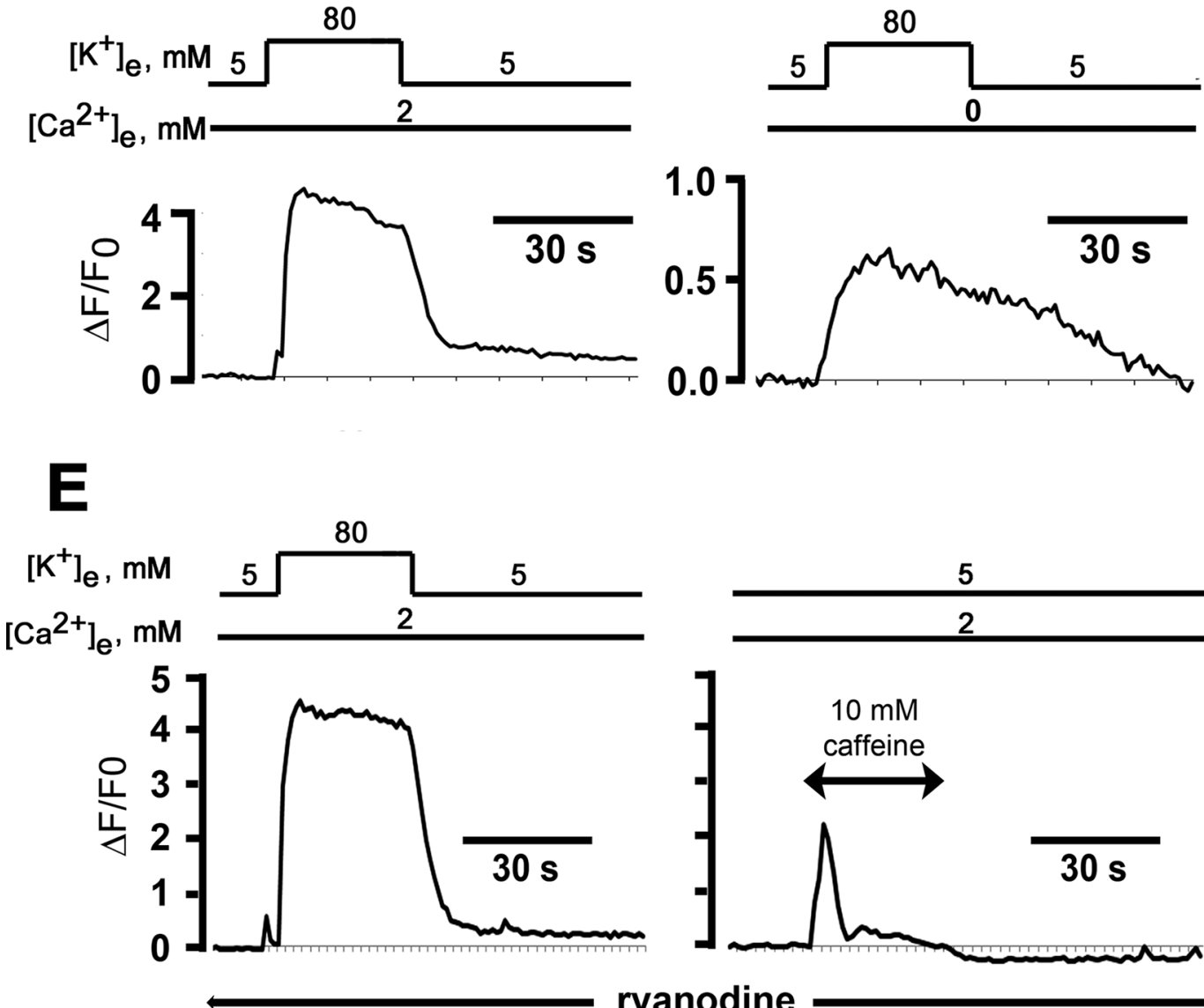

\section{ryanodine}

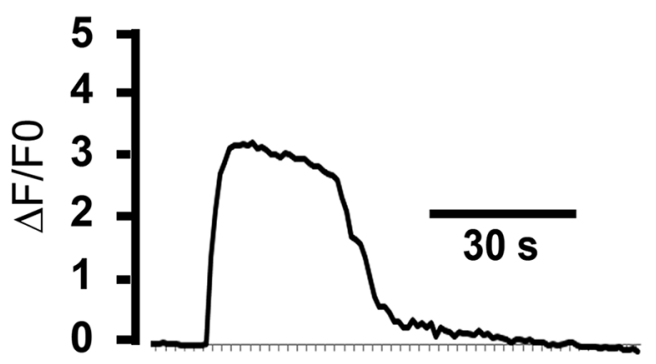

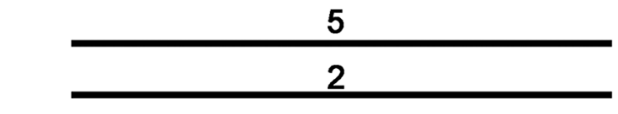
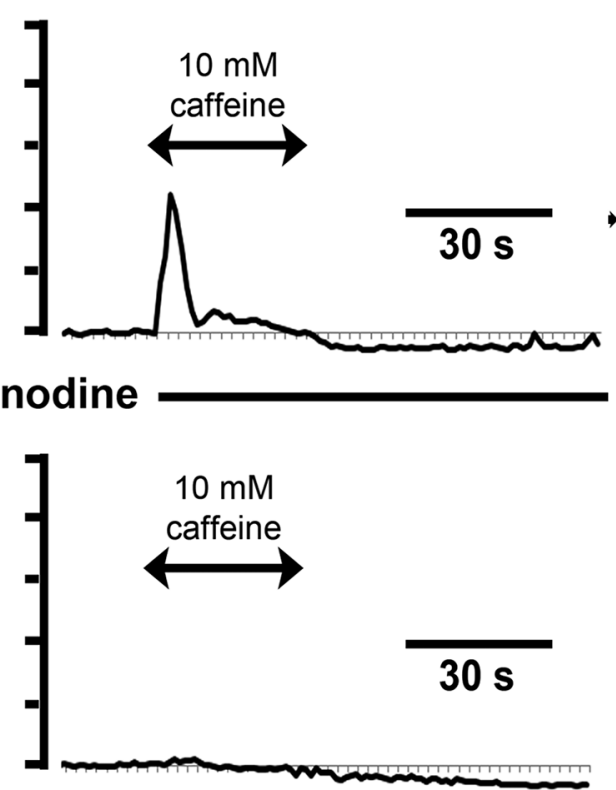

B

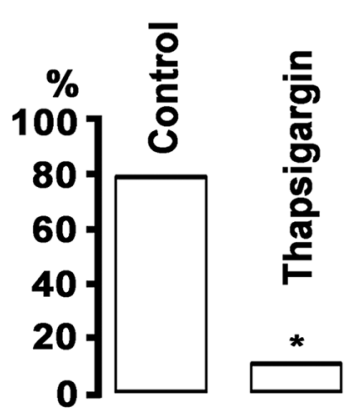

D

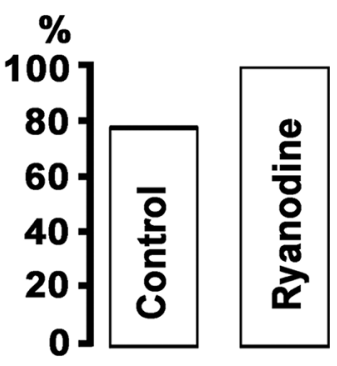


Fig 4. Thapsigargin, but not ryanodine, suppresses high $\left[\mathrm{K}^{+}\right]_{\mathrm{e}}$-induced cytosolic $\mathrm{Ca}^{2+}$ transients in the absence, but not in the presence, of extracellular $\mathrm{Ca}^{2+}$. A: Time course of cytosolic $\Delta \mathrm{F} / \mathrm{F}_{0}$ during 30 -s exposures to $80 \mathrm{mM}\left[\mathrm{K}^{+}\right]_{\mathrm{e}}$ in $2 \mathrm{mM}\left[\mathrm{Ca}^{2+}\right]_{\mathrm{e}}$ (left panel) and in the absence of external Ca ${ }^{2+}$. To deplete internal $\mathrm{Ca}^{2+}$ stores, cells were continuously incubated with thapsigargin $(1 \mu \mathrm{M})$ starting 20 min before the first exposure to elevated $\left[\mathrm{K}^{+}\right]_{\mathrm{e}}$. $\mathbf{B}$ : Percentage of cells exhibiting $\left[\mathrm{Ca}^{2+}\right]_{\mathrm{i}}$ transients both in $2 \mathrm{mM}$ and $0 \mathrm{mM}\left[\mathrm{Ca}^{2+}\right]_{e} ;{ }^{*} P<0.001$ versus control by Fisher Exact test (60 cells for control and 19 cells for thapsigargin). C: Time course of changes in cytosolic $\Delta \mathrm{F} / \mathrm{F}_{0}$ elicited by consecutive 30 -s exposures to $80 \mathrm{mM}\left[\mathrm{K}^{+}\right]_{\mathrm{e}}$ in normal $\left[\mathrm{Ca}{ }^{2+}\right]_{\mathrm{e}}($ upper panel) and in $\mathrm{Ca}^{2+}$-free bath solution (with $200 \mu \mathrm{M} \mathrm{EGTA}$ added). The cell was continuously incubated with ryanodine $(20 \mu \mathrm{M})$ starting $20 \mathrm{~min}$ before the first $\left[\mathrm{K}^{+}\right]_{\mathrm{e}}$ challenge. D: Percentage of cells exhibiting $\left[\mathrm{Ca}^{2+}\right]_{\mathrm{i}}$ transients both in $2 \mathrm{mM}$ and $0 \mathrm{mM}\left[\mathrm{Ca}^{2+}\right]_{\mathrm{e}} ; P=$ non-significant versus control by Fisher's Exact test (60 cells for control and 14 cells for ryanodine). E: Ryanodine depletes caffeine-sensitive internal $\mathrm{Ca}^{2+}$ stores in postganglionic sympathetic neurons. Time course of changes in cytosolic $\Delta \mathrm{F} / \mathrm{F}_{0}$ in response to a 30 -s exposure to $80 \mathrm{mM}\left[\mathrm{K}^{+}\right]_{\mathrm{e}}$ followed by a 30 -s exposure to caffeine (upper panel). Preincubation with $20 \mu \mathrm{M}$ ryanodine abrogated the caffeine-, but not the high $\left[\mathrm{K}^{+}\right]_{e}^{-}$, induced cytosolic $\mathrm{Ca}^{2+}$ transient (lower panel). Caffeine responses in the presence and absence of ryanodine were monitored in two different cells.

doi:10.1371/journal.pone.0148962.g004

drug with those recorded in its absence. We found no significant differences in resting membrane potential or potentials obtained during the $80-\mathrm{mM}\left[\mathrm{K}^{+}\right]_{\mathrm{e}}$ challenges either in normal Ca${ }^{2}$ ${ }^{+}$or $\mathrm{Ca}^{2+}$-free bath solutions $(P>0.05)$ among the two experimental groups (Table 2$)$. Collectively, these results indicate that thapsigargin-induced abolition of high $\left[\mathrm{K}^{+}\right]_{\mathrm{e}}-\mathrm{Ca}^{2+}$ transients in $0 \mathrm{mM}\left[\mathrm{Ca}^{2+}\right]_{\mathrm{e}}$ does not result from a collapse of the membrane potential but rather supports the notion that depolarization elicits $\mathrm{Ca}^{2+}$ release from intracellular stores independently of $\mathrm{Ca}^{2+}$ influx.

Depolarization-evoked cytosolic $\mathrm{Ca}^{2+}$ transients in the absence of extracellular $\mathrm{Ca}^{2+}$ could result from conformational coupling between $\mathrm{L}$-type $\mathrm{Ca}^{2+}$ channels and ryanodine receptors, as in skeletal muscle excitation-contraction coupling [4,19]. Accordingly, we examined the effect of pharmacological blocking $\mathrm{Ca}^{2+}$ release from ryanodine-sensitive stores on depolarization-induced $\mathrm{Ca}^{2+}$ release. We found that pretreating neurons for $20 \mathrm{~min}$ with ryanodine $(20 \mu \mathrm{M})$ spared the high $\left[\mathrm{K}^{+}\right]_{\mathrm{e}}$-induced $\mathrm{Ca}^{2+}$ responses both in the presence and absence of extracellular $\mathrm{Ca}^{2+}$ (Fig 4C). Overall, there was no significant difference in the proportion of neurons exhibiting $\left[\mathrm{K}^{+}\right]$-induced $\mathrm{Ca}^{2+}$ elevations in $0 \mathrm{mM}\left[\mathrm{Ca}^{2+}\right]_{\mathrm{e}}$ between the ryanodine [14 (100\%) of 14 cells] and the control group [ 47 (78\%) of 60 cells; $P>0.05$; Fig 4D]. As a probe for ryanodine receptor function, we applied caffeine $(10 \mathrm{mM})$, an agonist of ryanodine receptor-mediated $\mathrm{Ca}^{2+}$ release, and monitored intracellular $\left[\mathrm{Ca}^{2+}\right]$. Exposures to $80 \mathrm{mM}\left[\mathrm{K}^{+}\right]_{\mathrm{e}}$ and caffeine both reversibly elevated cytosolic $\left[\mathrm{Ca}^{2+}\right]$. Pretreatment with $20 \mu \mathrm{M}$ ryanodine abrogated the caffeine response, but did not affect the high $\left[\mathrm{K}^{+}\right]_{\mathrm{e}}$-induced response, which is consistent with previous studies (Fig 4E) [10], but differs from other studies demonstrating changes of $\left[\mathrm{Ca}^{2+}\right]_{\mathrm{i}}$ transient amplitude and/or kinetics by ryanodine $[14,18]$. Identical observations were made in 3 more cells. Thus, depolarization-evoked $\mathrm{Ca}^{2+}$ release in sympathetic ganglion neurons does not require ryanodine receptors, ruling out a skeletal muscle excitation-contraction coupling-like mechanism.

We then examined the contribution of $\mathrm{Ca}^{2+}$ release from $\mathrm{IP}_{3}$-sensitive $\mathrm{Ca}^{2+}$ stores to depolarization-induced $\mathrm{Ca}^{2+}$ transients in the absence of external $\mathrm{Ca}^{2+}$. Previous studies had demonstrated that depolarization of insect dorsal unpaired neurons in the absence of external $\mathrm{Ca}^{2+}$ triggers $\mathrm{Ca}^{2+}$ release from $\mathrm{IP}_{3}$-sensitive stores [6]. To determine whether $\mathrm{IP}_{3}$ receptors

Table 2. Membrane potentials of postganglionic sympathetic neurons at rest and during exposure to $80 \mathrm{mM}\left[\mathrm{K}^{+}\right]_{\mathrm{e}}$ in normal $\left[\mathrm{Ca}^{2+}\right]_{\mathrm{e}}$ and in the absence of extracellular $\mathrm{Ca}^{2+}$ (with $200 \mu \mathrm{M}$ EGTA added to the bath solution). Values are expressed as means \pm SEM. $\mathrm{n}$ indicates the number of cells. There were no statistically significant differences in the membrane potential between the treatment groups $(P>0.05$ by One Way Analysis of Variance).

\begin{tabular}{cccc}
\hline Treatment & Control $(\mathbf{m V}, \mathbf{n}=\mathbf{6})$ & $\mathbf{1} \boldsymbol{\mu M}$ Thapsigargin $(\mathbf{m V}, \mathbf{n}=\mathbf{9})$ & $\mathbf{2 0} \boldsymbol{\mu M} \mathbf{2 - A P B}(\mathbf{m V}, \mathbf{n}=\mathbf{4})$ \\
\hline $5 \mathrm{mM}\left[\mathrm{K}^{+}\right]_{\mathrm{e}}+2 \mathrm{mM}\left[\mathrm{Ca}^{2+}\right]_{\mathrm{e}}$ & $-61.8 \pm 4.4$ & $-62.1 \pm 2.6$ & $-67.7 \pm 3.1$ \\
$80 \mathrm{mM}\left[\mathrm{K}^{+}\right]_{\mathrm{e}}+2 \mathrm{mM}\left[\mathrm{Ca}^{2+}\right]_{\mathrm{e}}$ & $-15.7 \pm 0.5$ & $-15.3 \pm 1.4$ & $-11.1 \pm 2.2$ \\
$5 \mathrm{mM}\left[\mathrm{K}^{+}\right]_{\mathrm{e}}+0 \mathrm{mM}\left[\mathrm{Ca}^{2+}\right]_{\mathrm{e}}$ & $-59.9 \pm 3.1$ & $-55.6 \pm 2.2$ & $-63.4 \pm 4.0$ \\
$80 \mathrm{mM}\left[\mathrm{K}^{+}\right]_{\mathrm{e}}+0 \mathrm{mM}\left[\mathrm{Ca}^{2+}\right]_{\mathrm{e}}$ & $-18.5 \pm 0.8$ & $-18.8 \pm 1.3$ & $-14.6 \pm 2.0$ \\
\hline
\end{tabular}

doi:10.1371/journal.pone.0148962.t002 
contribute to depolarization-evoked $\mathrm{Ca}^{2+}$ signaling in sympathetic ganglion neurons, we pharmacologically blocked release from $\mathrm{IP}_{3}$-sensitive stores and then measured $80 \mathrm{mM}\left[\mathrm{K}^{+}\right]_{\mathrm{e}^{-}}$ induced changes in cytosolic $\left[\mathrm{Ca}^{2+}\right]$. We found that pretreating the neurons for $20 \mathrm{~min}$ with the $\mathrm{IP}_{3}$ receptor inhibitors 2 -aminoethoxydiphenyl borate (2-APB; $20 \mu \mathrm{M}$ ) or xestospongin $\mathrm{C}$ $(10 \mu \mathrm{M})$ abolished the $\left[\mathrm{K}^{+}\right]_{\mathrm{e}}$-evoked $\mathrm{Ca}^{2+}$ transient in the absence, but not in the presence, of extracellular $\mathrm{Ca}^{2+}$ (Fig 5A). Overall, exposure to elevated $\left[\mathrm{K}^{+}\right]_{\mathrm{e}}$ in $0 \mathrm{mM}\left[\mathrm{Ca}^{2+}\right]_{\mathrm{e}}$ induced $\mathrm{Ca}^{2+}$ transients in only $1(17 \%)$ of 62 -APB-treated and $2(10.5 \%)$ of 16 xestospongin C- treated neurons, compared to $47(78 \%)$ of 60 control neurons $(P=0.001$; Fig $5 \mathrm{~B})$. The prevalence of nonresponding cells was similar following treatment with 2 -APB or xestospongin $\mathrm{C}(P>0.05)$. Further, we found no significant differences in resting membrane potential or potentials obtained during the $80-\mathrm{mM}\left[\mathrm{K}^{+}\right]_{\mathrm{e}}$ challenges either in normal $\left[\mathrm{Ca}^{2+}\right]_{\mathrm{e}}$ or $\mathrm{Ca}^{2+}$-free bath solutions $(P>0.05)$ between control neurons and neurons following $\mathrm{IP}_{3}$ receptor blockade (Table 2). Collectively, these results support the notion that membrane depolarization in the absence of extracellular $\mathrm{Ca}^{2+}$ triggers $\mathrm{Ca}^{2+}$ release from $\mathrm{IP}_{3}$-sensitive internal stores, leading to slow rises in cytosolic $\left[\mathrm{Ca}^{2+}\right]$.

\section{Depolarization-evoked $\mathrm{Ca}^{2+}$ release in the absence of extracellular $\mathrm{Ca}^{2+}$ does not require L-type $\mathrm{Ca}^{2+}$ channels}

Voltage-dependent changes in L-type $\mathrm{Ca}^{2+}$ channel (dihydropyridine receptor) gating have previously been identified as the mechanism linking membrane depolarization to $\mathrm{Ca}^{2+}$ release from $\mathrm{IP}_{3}$-sensitive stores in skeletal myotubes in the absence of extracellular $\mathrm{Ca}^{2+}$ [20]. If an identical mechanism is at work in sympathetic ganglion neurons, we would expect the 1,4-dihydropyridine L-type $\mathrm{Ca}^{2+}$ channel antagonist nifedipine, which acts on the channel by immobilizing its gating charge, to affect depolarization-evoked $\mathrm{Ca}^{2+}$ transients. Measurements of whole-cell currents through high voltage-activated $\mathrm{Ca}^{2+}$ channels (with $\mathrm{Ba}^{2+}$ as charge carrier) revealed that a high concentration of nifedipine $(50 \mu \mathrm{M})$ was required to achieve a small $(\sim-20 \%)$, yet significant, reduction in current amplitude (Fig 6A-6C). The finding that nifedipine at $10 \mu \mathrm{M}$ did not block $I_{\mathrm{Ba}}$ strongly suggests a lack of functional L-type $\mathrm{Ca}^{2+}$ channels in adult sympathetic ganglion neurons, whereas the significant reduction of $I_{\mathrm{Ba}}$ at $50 \mu \mathrm{M}$ nifedipine may reflect inhibition of $\mathrm{Ca}_{\mathrm{v}} 2 . \mathrm{x}$ channels [21]. Alternatively, the insensitivity of whole-cell $I_{\mathrm{Ba}}$ to inhibition by nifedipine may suggest that adult sympathetic ganglion neurons express the skeletal muscle isoform of the L-type $\mathrm{Ca}^{2+}$ channel which has been shown previously to require nearly $50 \mu \mathrm{M}$ nifedipine for complete block [22]. We found that pretreating neurons for $20 \mathrm{~min}$ with a high concentration of nifedipine $(50 \mu \mathrm{M})$ spared the high $\left[\mathrm{K}^{+}\right]_{\mathrm{e}}$-induced $\mathrm{Ca}^{2+}$ responses both in the presence and absence of extracellular $\mathrm{Ca}^{2+}$ (Fig 6D). The lack of a significant effect of nifedipine on the magnitude of depolarization-evoked $\mathrm{Ca}^{2+}$ transients in the presence of normal $\left[\mathrm{Ca}^{2+}\right]_{\mathrm{e}}$ is consistent with the notion that $\mathrm{Ca}^{2+}$ entry via $\mathrm{L}$-type $\mathrm{Ca}^{2+}$ channels does not contribute noticeably to the rise in global $\left[\mathrm{Ca}^{2+}\right]$ in our study. Overall, there was no significant difference in the proportion of neurons exhibiting $\left[\mathrm{K}^{+}\right]$-induced $\mathrm{Ca}^{2+}$ elevations in $0 \mathrm{mM}\left[\mathrm{Ca}^{2+}\right]_{\mathrm{e}}$ between the nifedipine $[10(100 \%)$ of 10 cells] and the control group [47 $(78 \%)$ of 60 cells; $P>0.05$; Fig $6 \mathrm{E}]$. Collectively, these results support the notion that high $\left[\mathrm{K}^{+}\right]_{\mathrm{e}}$-evoked Ca ${ }^{2+}$ release in the absence of extracellular $\mathrm{Ca}^{2+}$ does not require L-type $\mathrm{Ca}^{2+}$ channels.

\section{Depolarization-induced $\left[\mathrm{Ca}^{2+}\right]_{\mathrm{i}}$ transients in the absence of extracellular calcium are not blocked by extracellular cadmium}

Voltage-gated calcium channels become permeable to monovalent cations when extracellular calcium concentrations fall to sub-micromolar levels [23], suggesting the possibility that 
A

$\left[\mathrm{Ca}^{2+}\right]_{e}, \mathrm{mM}$

2

80
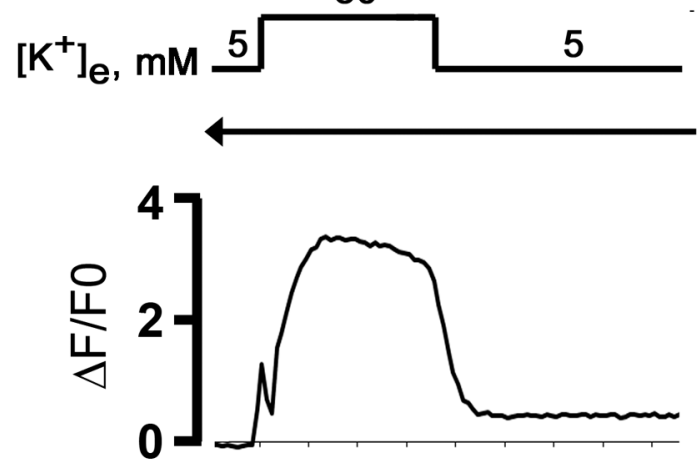

0

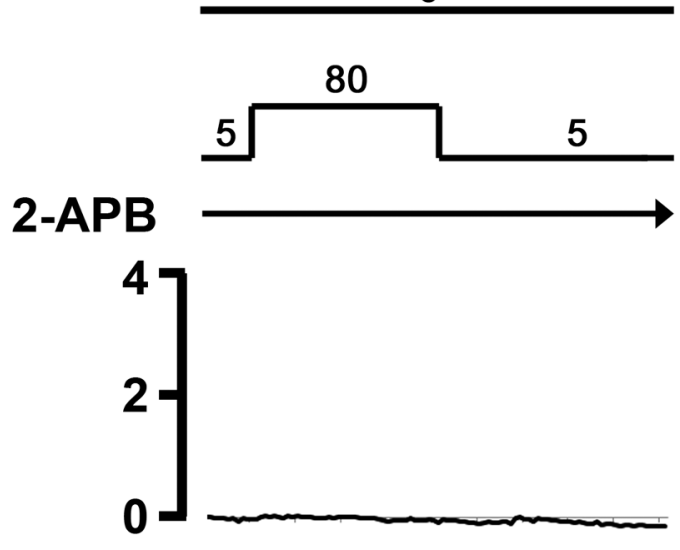

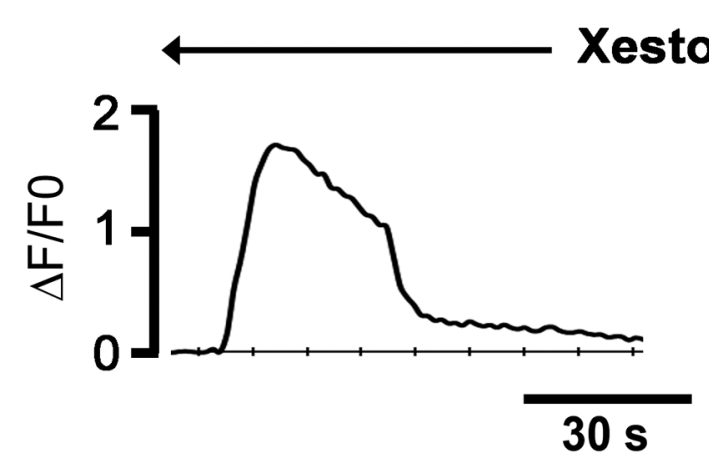

ospongin C

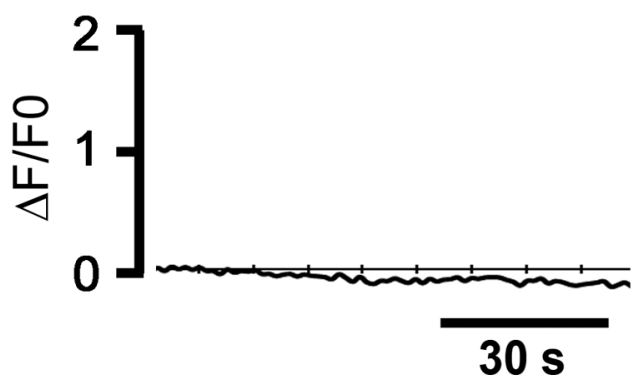

B

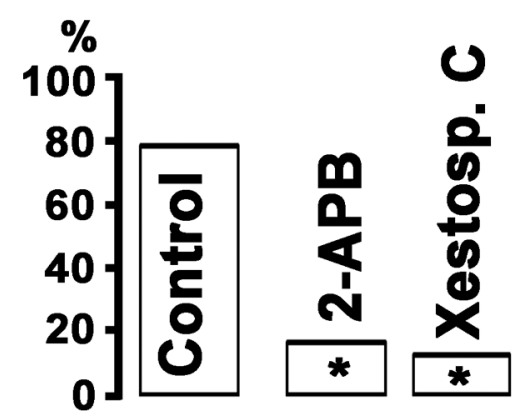

Fig 5. Pharmacological inhibitors of $\mathrm{IP}_{3}$ receptors abrogate high $\left[\mathrm{K}^{+}\right]_{e}$-induced $\mathrm{Ca}^{2+}$ transients in $\mathrm{Ca}^{2+}$-free bath solution. A: Representative time courses of changes in cytosolic $\Delta F / F_{0}$ in response to two consecutive 30 -s exposures to $80 \mathrm{mM}\left[\mathrm{K}^{+}\right]_{\mathrm{e}}$ in $2 \mathrm{mM}\left[\mathrm{Ca}^{2+}\right]_{\mathrm{e}}\left(\mathrm{left}\right.$ panels) and in Ca ${ }^{2+}$-free bath solution (with $200 \mu \mathrm{M}$ EGTA added; right panels) following 20-min incubation with $20 \mu \mathrm{M} 2$-APB or $10 \mu \mathrm{M}$ xestospongin C. B: Percentage of neurons exhibiting $\left[\mathrm{Ca}^{2+}\right]_{i}$ transients both in $2 \mathrm{mM}$ and $0 \mathrm{mM}\left[\mathrm{Ca}^{2+}\right]_{e} ;{ }^{*} P<0.001$ versus control by Fisher's Exact test $(60,6$ and 16 cells for control, $2-\mathrm{APB}$ and xestospongin $\mathrm{C}$, respectively).

doi:10.1371/journal.pone.0148962.g005

depolarization-induced $\left[\mathrm{Ca}^{2+}\right]_{\mathrm{i}}$ increases in the absence of external $\mathrm{Ca}^{2+}$ are triggered by influx of $\mathrm{Na}^{+}$and/or $\mathrm{K}^{+}$through open calcium channels under our experimental conditions. Accordingly, we next examined the effect of pharmacologically inhibiting ion flux through high voltage-gated $\mathrm{Ca}^{2+}$ channels on $\left[\mathrm{K}^{+}\right]_{\mathrm{e}}-\mathrm{Ca}^{2+}$ transients in $0 \mathrm{mM}\left[\mathrm{Ca}^{2+}\right]_{\mathrm{e}}$. Extracellular $\mathrm{Cd}^{2+}$ has 
A
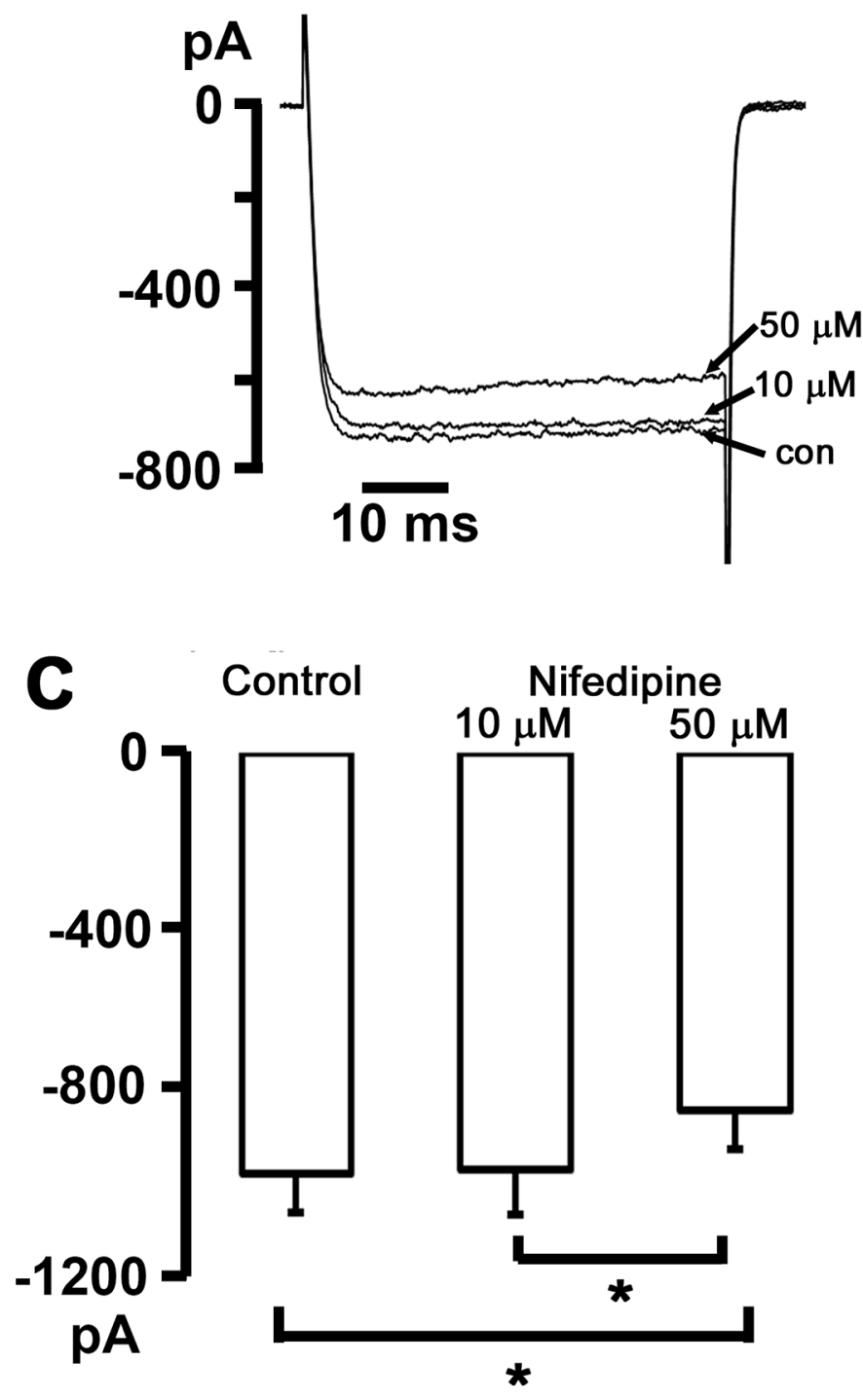

$\mathbf{E}$

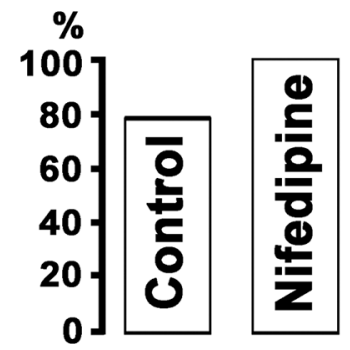

B

\section{pA}

$-800$

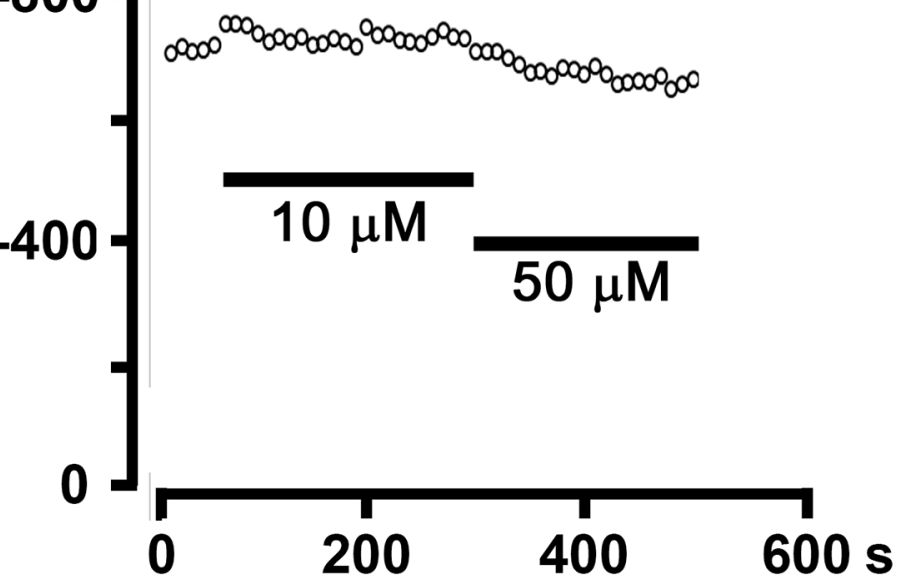

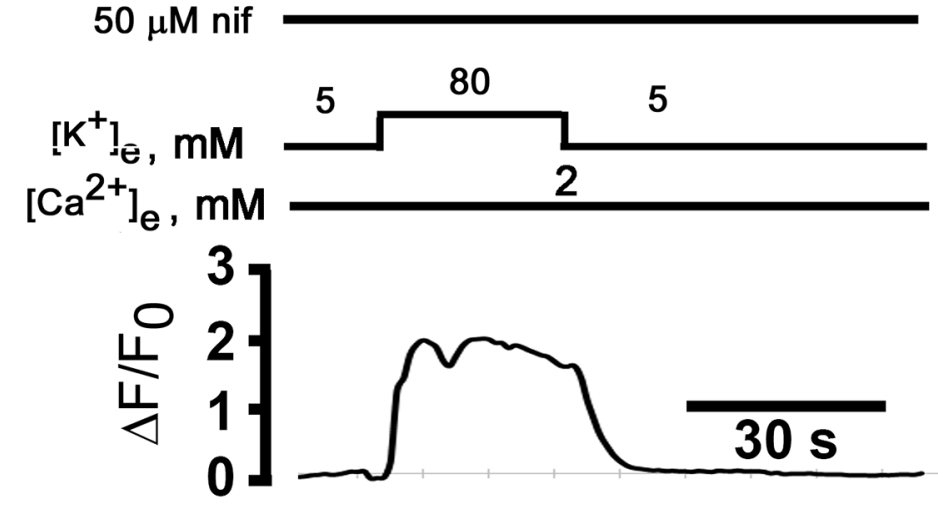
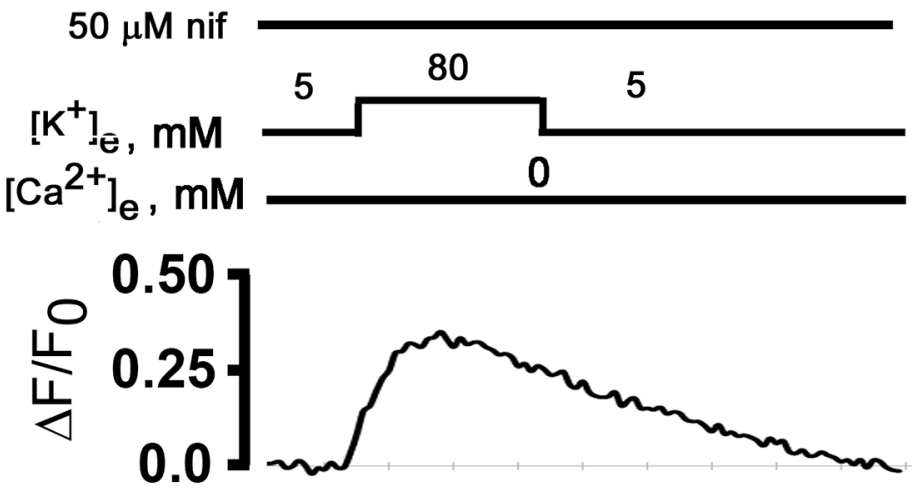

Fig 6. The 1,4-dihydropyridine antagonist of L-type $\mathrm{Ca}^{2+}$ channels, nifedipine, does not affect $\mathrm{Ca}^{2+}$ transients elicited by exposure to elevated $\left[\mathrm{K}^{+}\right]_{\mathrm{e}}$. A and $\mathbf{B}$ : The response of peak $I_{B a}$ in a postganglionic sympathetic neuron to application of 10 and $50 \mu \mathrm{M}$ nifedipine. $I_{B a}$ was activated by depolarizations from $-80 \mathrm{mV}$ to $10 \mathrm{mV}$ every 10 seconds. Representative current traces are shown in A. C: Bar graphs represent the average peak $I_{B a}$ in control and in 10 and $50 \mu \mathrm{M}$ nifedipine. Values are from 10 cells. ${ }^{*} P<0.05$, RM ANOVA on ranks followed by Student-Newman-Keuls Method for multiple comparisons. D: Exemplar time courses of changes in cytosolic $\Delta F / F_{0}$ elicited by $80 \mathrm{mM}\left[\mathrm{K}^{+}\right]_{\mathrm{e}}$ in the presence (upper panel) and absence of external Ca ${ }^{2+}$. The cell was continuously bathed in $50 \mu \mathrm{M}$ nifedipine starting $20 \mathrm{~min}$ before the first $\left[\mathrm{K}^{+}\right]_{\mathrm{e}}$ test. E: Percentage of cells exhibiting [Ca $\left.{ }^{2+}\right]_{\mathrm{i}}$ transients both in $2 \mathrm{mM}$ and $0 \mathrm{mM}\left[\mathrm{Ca}^{2+}\right]_{\mathrm{e}} ; P=$ non-significant versus control by Fisher Exact test (60 cells for control and 10 cells for nifedipine).

doi:10.1371/journal.pone.0148962.g006 
been shown previously to potently block ion flux through neuronal, high voltage-gated calcium channels in a concentration-dependent manner [10], without altering channel gating. Our measurements of whole-cell $\mathrm{Ca}^{2+}$ currents in voltage-clamped neurons (using $\mathrm{Ba}^{2+}$ as the charge carrier) confirmed the absence of resolvable inward currents following the addition of $300 \mu \mathrm{M} \mathrm{Cd}^{2+}$ to the bath solution (S1A-S1C Fig), supporting the notion that $\mathrm{Cd}^{2+}$ at this concentration potently blocked currents through voltage-activated $\mathrm{Ca}^{2+}$ channels, consistent with previous studies in adult sympathetic ganglion neurons [9,24]. In addition, $\mathrm{Cd}^{2+}$ at concentrations that block ion flux has been reported to not affect membrane potential of sympathetic ganglion neurons [10]. Thus, extracellular $\mathrm{Cd}^{2+}$ in micromolar concentrations should be ideally suited to distinguish a role of ion flux through versus gating of voltage-dependent $\mathrm{Ca}^{2+}$ channels in mediating depolarization-induced rise in $\left[\mathrm{Ca}^{2+}\right]_{\mathrm{i}}$ in $0 \mathrm{mM}\left[\mathrm{Ca}^{2+}\right]_{\mathrm{e}}$. A typical $\Delta \mathrm{F} /$ $\mathrm{F}_{0}$ response of a sympathetic ganglion neuron to a 30 -s exposure to $80 \mathrm{mM}\left[\mathrm{K}^{+}\right]_{\mathrm{e}}$ and $300 \mu \mathrm{M}$ $\mathrm{Cd}^{2+}$ in the absence of external $\mathrm{Ca}^{2+}$ is shown in Fig 7A. In these conditions, high $\left[\mathrm{K}^{+}\right]_{\mathrm{e}}$ still caused an increase in $\Delta \mathrm{F} / \mathrm{F}_{0}$, with no sign of recovery following return to $5 \mathrm{mM}\left[\mathrm{K}^{+}\right]_{\mathrm{e}}$. The irreversible increase in fluo- 4 fluorescence resulted from $\mathrm{Cd}^{2+}$ influx into the cell, because it was completely reversed by a 5 -min incubation with the membrane-permeant divalent metal chelator tetrakis (2-pyridylmethyl) ethylendiamine (TPEN; $100 \mu \mathrm{M}$; Fig 7B), whose affinity for $\mathrm{Cd}^{2+}$ $\left(K_{d}=10^{-12} \mathrm{M}\right)$ [25] is several orders of magnitude higher than that for $\mathrm{Ca}^{2+}\left(K_{d}=10^{-4.4} \mathrm{M}\right)$ [26]. The means of high $\left[\mathrm{K}^{+}\right]_{\mathrm{e}}$-induced changes in peak $\Delta \mathrm{F} / \mathrm{F}_{0}$ in the presence of $2 \mathrm{mM}\left[\mathrm{Ca}^{2+}\right]_{\mathrm{e}}$ were not significantly different before and after loading with TPEN (Fig 7C), suggesting that TPEN can be used to selectively suppress the $\mathrm{Cd}^{2+}$ influx-dependent component of the fluo- 4 signal in our experimental conditions. Indeed, combined exposure of another TPEN-loaded neuron to $80 \mathrm{mM}\left[\mathrm{K}^{+}\right]_{\mathrm{e}}$ and $300 \mu \mathrm{M} \mathrm{Cd}^{2+}$ in the absence of external $\mathrm{Ca}^{2+}$ revealed the typical $\Delta \mathrm{F} / \mathrm{F}_{0}$ response pattern seen in the absence of $\mathrm{Cd}^{2+}$, i.e., the increase in $\Delta \mathrm{F} / \mathrm{F}_{0}$ readily resolved following return to physiological $\left[\mathrm{K}^{+}\right]_{\mathrm{e}}$ (Fig 7D). Identical observations were made in 4 other TPEN-loaded neurons.

To further examine whether voltage-dependent $\mathrm{Ca}^{2+}$ channels conduct $\mathrm{Na}^{+}$currents in the absence of extracellular $\mathrm{Ca}^{2+}$, we sequentially measured macroscopic currents carried by these channels in 2 and $0 \mathrm{mM}\left[\mathrm{Ca}^{2+}\right]_{\mathrm{e}}$. Extracellular concentrations of $\mathrm{Mg}^{2+}(2 \mathrm{mM})$ and $\mathrm{Na}^{+}$ $(140 \mathrm{mM})$ remained unchanged. Tetrodotoxin $(1 \mu \mathrm{M})$ was present in the bath solution throughout the measurements to block voltage-gated $\mathrm{Na}^{+}$channels. Exemplar whole-cell current traces acquired in response to step depolarizations to $+10 \mathrm{mV}$ before and after $\mathrm{Ca}^{2+}$ withdrawal are shown in Fig 8A. Removal of extracellular $\mathrm{Ca}^{2+}$ resulted in loss of inward currents, indicating that voltage-gated $\mathrm{Ca}^{2+}$ channels do not carry resolvable $\mathrm{Na}^{+}$currents in the ionic conditions used here. Overall, these results support the notion that depolarization-induced rises in $\left[\mathrm{Ca}^{2+}\right]_{\mathrm{i}}$ in $0 \mathrm{mM}\left[\mathrm{Ca}^{2+}\right]_{\mathrm{e}}$ are not triggered by ion fluxes through high voltage-gated $\mathrm{Ca}^{2+}$ channels.

\section{Discussion}

Our results indicate that the increase in global cytosolic $\left[\mathrm{Ca}^{2+}\right]$ seen in response to prolonged depolarization in nominally $\mathrm{Ca}^{2+}$-free bath solution cannot be attributed to $\mathrm{Ca}^{2+}$ influx and subsequent $\mathrm{Ca}^{2+}$-induced $\mathrm{Ca}^{2+}$ release. Further, a skeletal muscle excitation-contraction-like mechanism as reported previously for hypothalamic magnocellular neurons, ischemically injured spinal cord white matter, and hippocampal neurons, can be excluded as the mechanism underlying depolarization-induced $\mathrm{Ca}^{2+}$ mobilization [3-5]. On the other hand, our findings are similar to those reported previously by Ryglewski et al. demonstrating that insect dorsal unpaired median neurons are capable of transducing incremental depolarization into gradual 
A
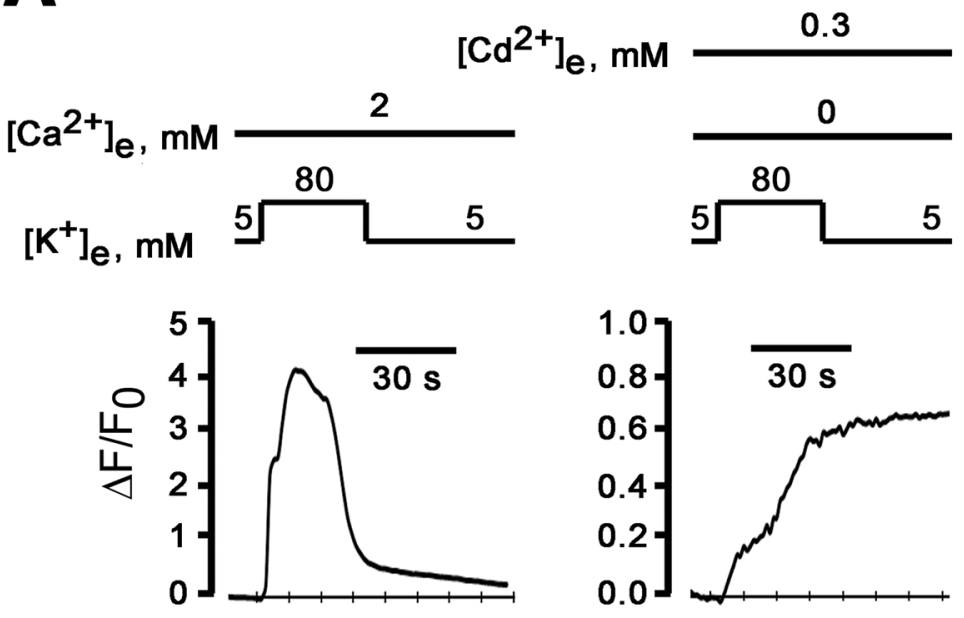

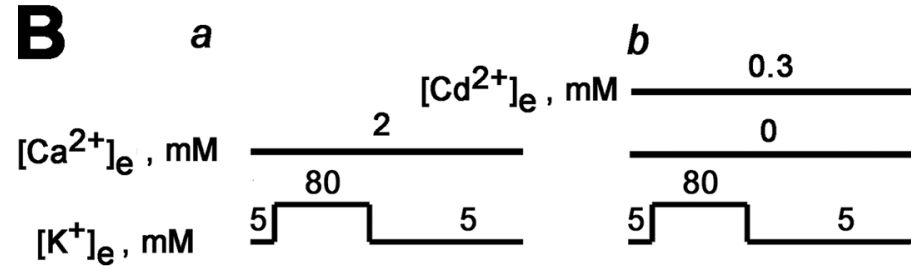

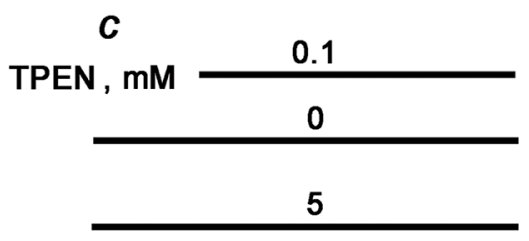

$d$
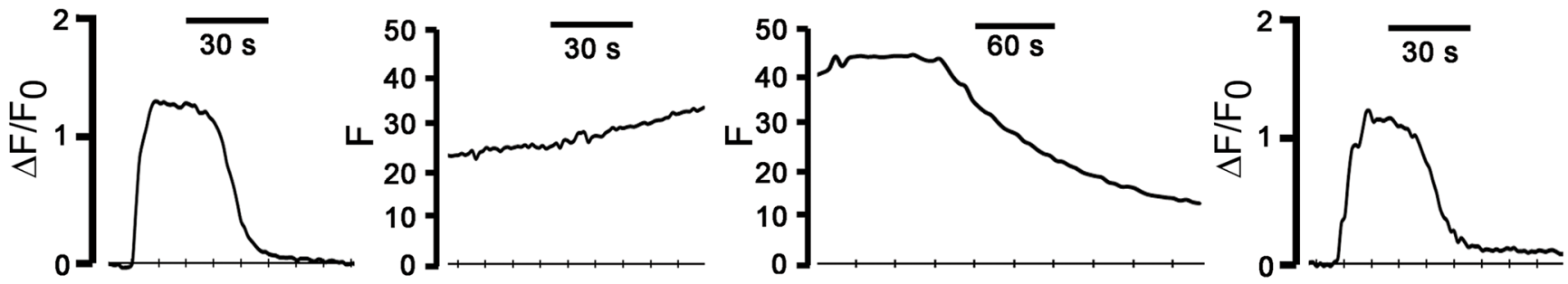

C

D
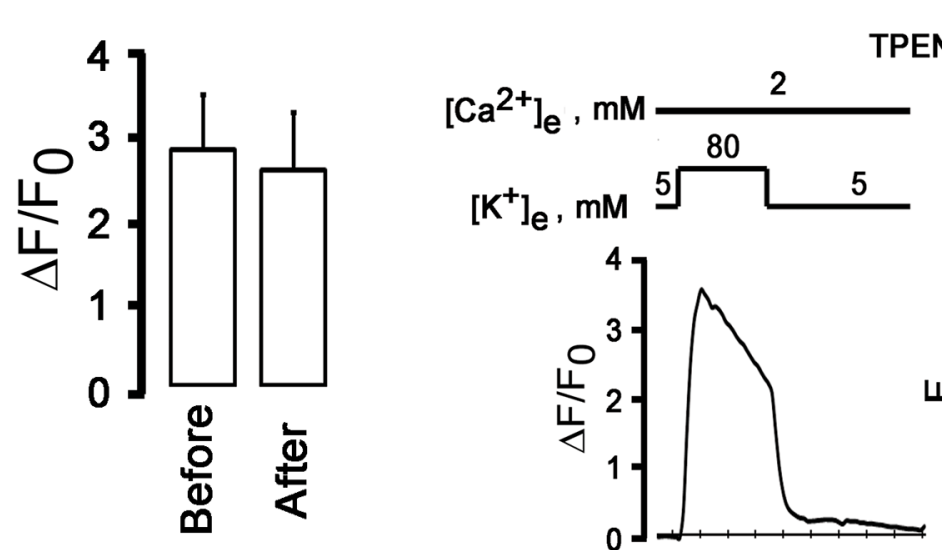

TPEN , mM
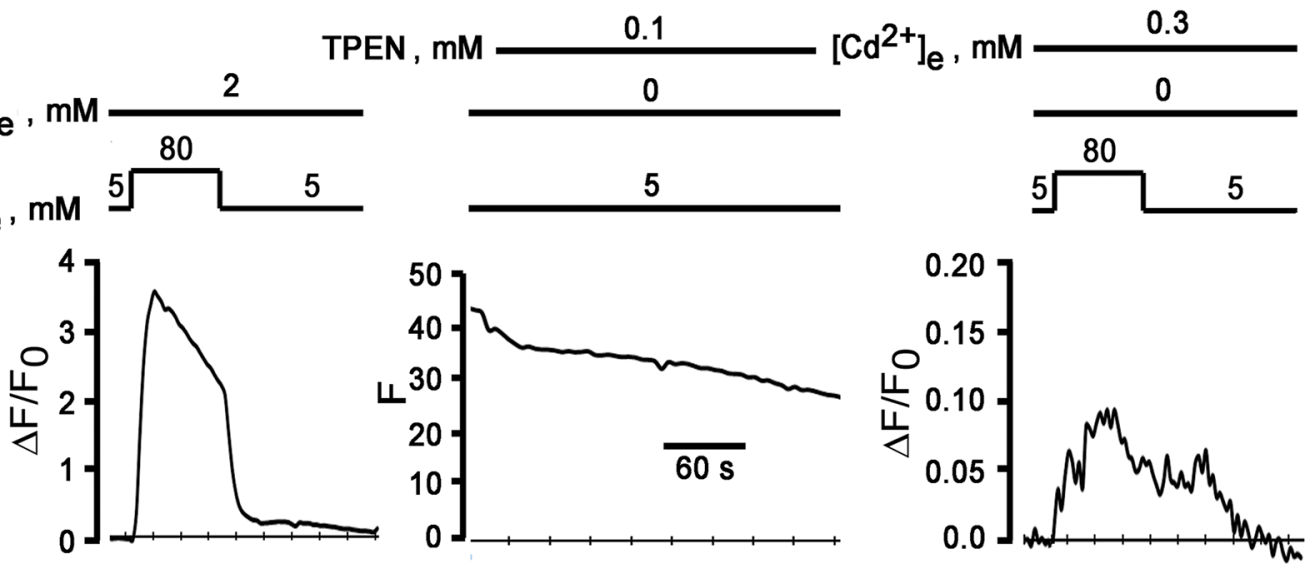
Fig 7. External $\mathrm{Cd}^{2+}$ does not suppress high $\left[\mathrm{K}^{+}\right]_{\mathrm{e}}$-induced $\Delta \mathrm{F} / \mathrm{F}_{\mathrm{o}}$ transients in $\mathbf{0} \mathrm{mM}\left[\mathrm{Ca}^{2+}\right]_{\mathrm{e}}$. $\mathrm{A}$ : Irreversible increase of $\Delta \mathrm{F} / \mathrm{F}_{0}$ in depolarized neurons in the presence of extracellular $\mathrm{Cd}^{2+}$. Shown are time courses of changes in cytosolic $\Delta \mathrm{F} / \mathrm{F}_{0}$ elicited by $80 \mathrm{mM}\left[\mathrm{K}^{+}\right]_{\mathrm{e}}$ in the presence of $2 \mathrm{mM} \mathrm{Ca}{ }^{2+}$ (left panel) and by $80 \mathrm{mM}\left[\mathrm{K}^{+}\right]_{\mathrm{e}}$ and $300 \mu \mathrm{M} \mathrm{Cd}^{2+}$ in a Ca ${ }^{2+}$-free bath solution (right panel). The increase of $\Delta \mathrm{F} / \mathrm{F}_{0}$ does not recover after removal of high-[ $\left.\mathrm{K}^{+}\right]_{\mathrm{e}}$-induced depolarization. B: External cadmium does not block depolarization-induced increase in cytosolic $\Delta F / F_{0}$ in the absence of extracellular Ca ${ }^{2+}$. (a) reversible increase in $\Delta F / F_{0}$ in response to a 30 -s exposure to $80 \mathrm{mM}\left[\mathrm{K}^{+}\right]_{e}$ in $2-\mathrm{mM} \mathrm{Ca}^{2+}$ bath solution. (b) and (c): a second exposure to $80 \mathrm{mM}^{2}\left[\mathrm{~K}^{+}\right]_{e}$ in Ca ${ }^{2+}$-free solution supplemented with $300 \mu \mathrm{M} \mathrm{CdCl}_{2}$ causes a sustained increase in fluo-4 fluorescence $(b)$ which is not reversed until treatment of the cell with the membrane permeable metal chelator TPEN at $100 \mu \mathrm{M}(c)$. A second $\mathrm{K}^{+}$challenge of the TPEN-loaded neuron in a 2-mM Ca ${ }^{2+}$ bath solution (d) shows restoration of fluo- $4 \mathrm{Ca}^{2+}$ responsivity. C: Bar graphs summarizing mean $\pm \mathrm{SEM}$ of peak cytosolic $\Delta \mathrm{F} / \mathrm{F}_{0}$ in sympathetic neurons before and after loading with TPEN $(100 \mu \mathrm{M}) . P=0.14$ by paired $t$-test $(\mathrm{n}=5 \mathrm{cells})$. $\mathrm{D}$ : Extracellular cadmium does not block depolarization-induced increase in $\Delta \mathrm{F} / \mathrm{F}_{0}$ in the absence of external $\mathrm{Ca}^{2+}$. Left panel: reversible increase in $\Delta \mathrm{F} / \mathrm{F}_{0}$ in response to a 30 -s exposure to $80 \mathrm{mM}\left[\mathrm{K}^{+}\right]_{\mathrm{e}}$ in $2 \mathrm{mM}\left[\mathrm{Ca}^{2+}\right]_{\mathrm{e}}$. Following TPEN loading (middle panel), a second $30-\mathrm{s}\left[\mathrm{K}^{+}\right]_{\mathrm{e}}$ challenge in a $\mathrm{Ca}^{2+}$-free bath solution containing $300 \mu \mathrm{M} \mathrm{Cd}^{2+}$ gives rise to a small-amplitude $\Delta \mathrm{F} / \mathrm{F}_{0}$ transient (right panel).

doi:10.1371/journal.pone.0148962.g007

increases in cytosolic $\left[\mathrm{Ca}^{2+}\right]$, involving $\mathrm{Ca}^{2+}$ - influx-independent activation of a $\mathrm{G}$ proteinphospholipase $\mathrm{C}-\mathrm{IP}_{3}$ receptor pathway. However, the nature of the voltage sensor was not identified in the latter study [6].

Na-induced dissociation of G-protein subunits has been demonstrated previously in neurons [27], suggesting the possibility that high $\left[\mathrm{K}^{+}\right]_{\mathrm{e}}$-evoked $\mathrm{Ca}^{2+}$ mobilization from $\mathrm{IP}_{3}$-sensitive stores as seen in the present study involves an ion influx-dependent, but not strictly depolarization-dependent, mechanism. Specifically, $\mathrm{Na}^{+}$permeation of voltage-gated $\mathrm{Ca}^{2+}$ channels in the absence of external $\mathrm{Ca}^{2+}$ is one possible pathway linking $\mathrm{Ca}^{2+}$ release to membrane depolarization in our experimental conditions. We think this possibility to be unlikely for several reasons. First, extracellular $\mathrm{Cd}^{2+}$ at concentrations that completely blocked inward currents through voltage-gated $\mathrm{Ca}^{2+}$ channels, did not suppress high $\left[\mathrm{K}^{+}\right]_{\mathrm{e}}-\left[\mathrm{Ca}^{2+}\right]_{\mathrm{i}}$ transients

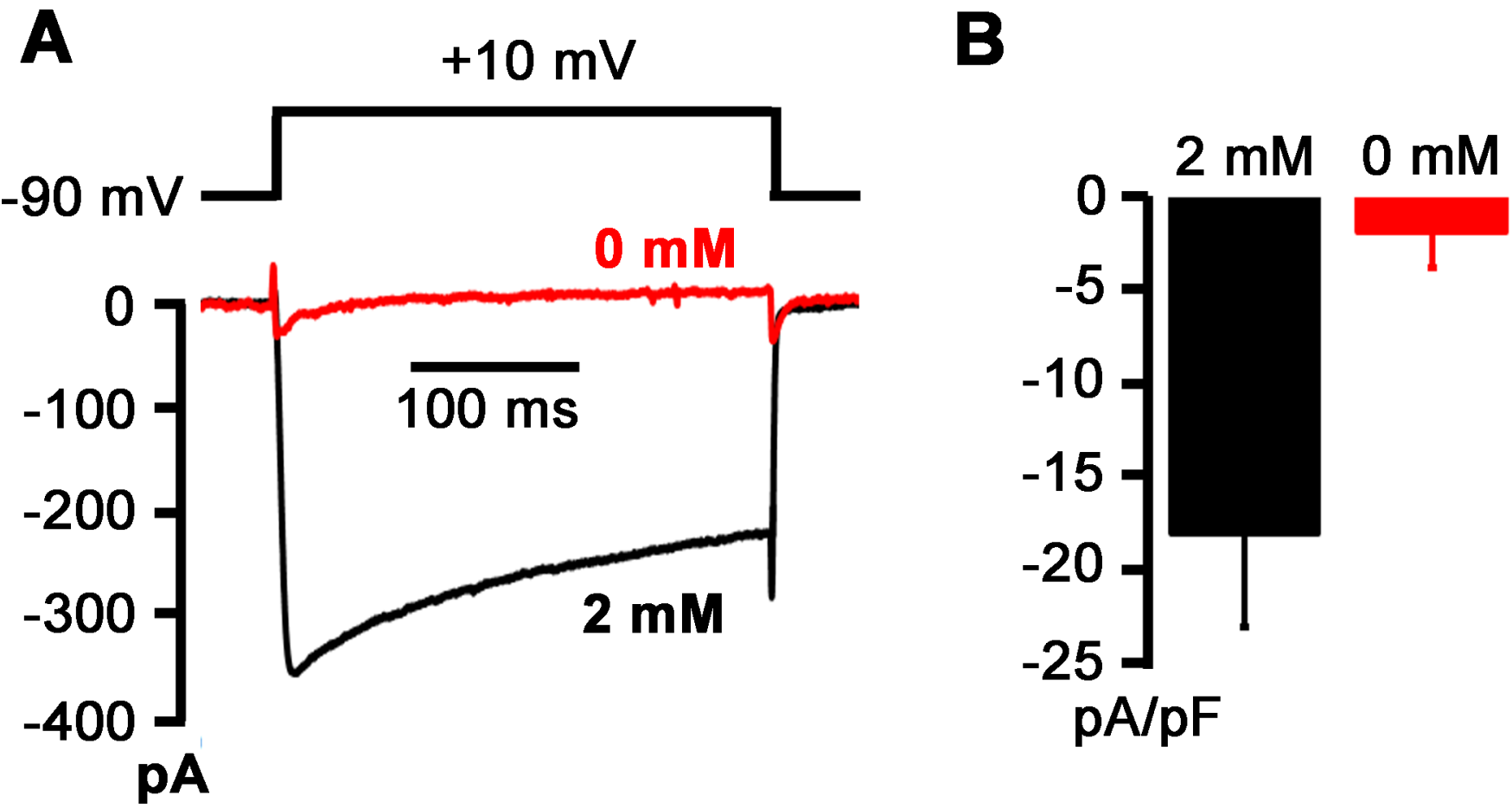

Fig 8. Voltage-gated $\mathrm{Ca}^{2+}$ channels do not conduct $\mathrm{Na}^{+}$after removal of extracellular $\mathrm{Ca}^{2+}$. A: Exemplar whole-cell current traces sequentially recorded in a voltage-clamped neuron during $300-\mathrm{ms}$ step depolarizations to $+10 \mathrm{mV}$ from a holding potential of $-90 \mathrm{mV}$ in 2 and $0 \mathrm{mM}^{2}\left[\mathrm{Ca}^{2+}\right]_{\mathrm{e}}$. The bath solution also contained $1 \mu \mathrm{M}$ tetrodotoxin to block voltage-gated $\mathrm{Na}^{+}$channels. Voltages were not corrected for liquid junction potential. Numbers in mM denote extracellular $\mathrm{Ca}^{2+}$ concentration. Voltage-clamp protocol is shown in the upper panel. B: Bar graph summarizing means of peak inward currents evoked by depolarizations to $+10 \mathrm{mV}$ in the presence and absence of external $\mathrm{Ca}^{2+}$ in the same cells. Error bars represent SEM $(n=4$ cells). $P=0.02$ versus $2 \mathrm{mM}$ $\left[\mathrm{Ca}^{2+}\right]_{\mathrm{e}}$ by paired $t$-test. 
in the absence of extracellular $\mathrm{Ca}^{2+}$. Second, we did not detect resolvable inward currents through voltage-dependent $\mathrm{Ca}^{2+}$ channels in voltage-clamped, depolarized neurons upon removal of extracellular $\mathrm{Ca}^{2+}$. Third, high $\left[\mathrm{K}^{+}\right]_{\mathrm{e}}-\mathrm{Ca}^{2+}$ transients in $\mathrm{Ca}^{2+}$-free bath solutions could be readily evoked in the presence of $1 \mathrm{mM}$ extracellular $\mathrm{Mg}^{2+}$, which corresponds to 4 times the $\mathrm{IC}_{50}$ of $\mathrm{Mg}^{2+}$-induced block of $\mathrm{Na}^{+}$current through $\mathrm{N}$-type $\mathrm{Ca}^{2+}$ channels [28], the major subtype of voltage-gated $\mathrm{Ca}^{2+}$ channels in adult sympathetic ganglion neurons.

Also, ions other than $\mathrm{Ca}^{2+}$ can enter the cell via alternative voltage-modulated pathways, e.g., voltage-gated $\mathrm{Na}^{+}$channels, or voltage-independent pathways, e.g., acetylcholine receptor and/or transient receptor potential cation channels. The gradual decrease in $\mathrm{Na}^{+}$concentration in the bath solution for increasingly large depolarizations results in an incremental reduction in the $\mathrm{Na}^{+}$driving force, progressively reducing its flux through voltage-independent channels as the membrane becomes more depolarized. This behavior conflicts with the non-monotonic dependence of depolarization-evoked peak $\Delta \mathrm{F} / \mathrm{F}_{0}$ amplitude on voltage that we observed in the absence of external $\mathrm{Ca}^{2+}$ (see Fig 2E). It thus appears unlikely that the magnitude of $\mathrm{Na}^{+}$movement through voltage-independent pathways constitutes the trigger for $\mathrm{Ca}^{2+}$ mobilization in our experiments. Because the relationship between changes in membrane potential and those in extracellular $\mathrm{K}^{+}$concentration followed the Nernst equation with a slope close to that expected for a $\mathrm{K}^{+}$-selective ion channel (see Fig $2 \mathrm{C}$ ), the $\mathrm{K}^{+}$net flux at each membrane potential achieved with various $\left[\mathrm{K}^{+}\right]_{\mathrm{e}}$ must have been zero or close to zero, excluding voltagedependent changes in transmembrane $\mathrm{K}^{+}$flux as a possible regulator of $\mathrm{Ca}^{2+}$ release in $0 \mathrm{mM}$ $\left[\mathrm{Ca}^{2+}\right]_{\mathrm{e}}$.

Finally, the possibility that the voltage-dependence of peak $\Delta \mathrm{F} / \mathrm{F}_{0}$ magnitude in the absence of external $\mathrm{Ca}^{2+}$ reflects the voltage-dependence of a steady-state current through voltagegated $\mathrm{Na}^{+}$channels has to be considered. Previous studies by others revealed the existence of a non-inactivating component of the $\mathrm{Na}^{+}$current in neurons [29], whose magnitude exhibits a non-monotonic, $\mathrm{U}$-shaped, dependence on voltage. However, these persistent, so-called 'window' $\mathrm{Na}^{+}$currents activated at voltages significantly more negative than those of peak $\Delta \mathrm{F} / \mathrm{F}_{0}$ in $0 \mathrm{mM}\left[\mathrm{Ca}^{2+}\right]_{\mathrm{e}}$, making persistent $\mathrm{Na}^{+}$currents an unlikely candidate linking $\mathrm{Ca}^{2+}$ discharge to membrane voltage changes. Overall, our results thus support the notion that depolarization per se suffices to trigger $\mathrm{Ca}^{2+}$ discharge from $\mathrm{IP}_{3}$-sensitive stores in $0 \mathrm{mM}\left[\mathrm{Ca}^{2+}\right]_{\mathrm{e}}$.

The inverse $\mathrm{U}$-shaped dependence of peak $\Delta \mathrm{F} / \mathrm{F}_{0}$ amplitude on membrane potential in 0 $\mathrm{mM}\left[\mathrm{Ca}^{2+}\right]_{\mathrm{e}}$ is both unexpected and puzzling. Because peak $P_{\text {act }}$ of voltage-gated $\mathrm{Ca}^{2+}$ channels steeply increases with depolarization over the range of membrane potentials we studied, we can exclude the possibility that gating changes as are typically achieved during peak activation of these channels, underlie voltage-induced, $\mathrm{Ca}^{2+}$ influx-independent $\mathrm{Ca}^{2+}$ release in our experiments. However, the observed non-monotonic behavior of $\mathrm{Ca}^{2+}$ signal strength with increasing depolarization is compatible with a mechanism, wherein the voltage-dependence of a channel's steady-state, but not peak, $P_{a c t}$ serves to transduce prolonged changes in membrane potential into graded $\mathrm{Ca}^{2+}$ mobilization. Indeed, our numerical simulations using experimentally determined activation and inactivation properties of voltage-activated $\mathrm{Ca}^{2+}$ channels demonstrate that the channel's voltage-dependence of steady-state $P_{a c t}$ on membrane potential overlaps with that of peak $\Delta \mathrm{F} / \mathrm{F}_{0}$ magnitude measured in $0 \mathrm{mM}\left[\mathrm{Ca}^{2+}\right]_{\mathrm{e}}$. Direct proof of the role of conformational changes of a $\mathrm{Ca}^{2+}$ channel complex in tuning $\mathrm{Ca}^{2+}$ discharge from $\mathrm{IP}_{3}$ sensitive internal stores will require experimental immobilization of gating charges in subtypes of voltage-gated $\mathrm{Ca}^{2+}$ channels known to be expressed in adult sympathetic ganglion neurons, including $\mathrm{N}$ - and $\mathrm{P} / \mathrm{Q}$-type $\mathrm{Ca}^{2+}$ channels. It will also require measurements of absolute free $\left[\mathrm{Ca}^{2+}\right]_{\mathrm{i}}$ levels. Because we have not calibrated the fluo- 4 signal for our experimental conditions, we were unable to directly correlate changes in membrane potential to those in free $\left[\mathrm{Ca}^{2+}\right]_{\mathrm{i}}$. 
Besides voltage-gated ion channels, it is possible that non-ion channel proteins act as voltage sensors, e.g., the Na-K ATPase, the $\mathrm{Na}-\mathrm{Ca}$ exchanger or the recently discovered voltage-sensitive phosphatide phosphatase, although expression of the latter in mammalian neuronal tissue has not yet been confirmed [30]. Additional studies are needed to identify the molecule capable of transducing the electrical signal into $\mathrm{Ca}^{2+}$ discharge from $\mathrm{IP}_{3}$-sensitive stores in adult sympathetic neurons.

It was demonstrated previously that insect dorsal unpaired median neurons possess a membrane voltage sensor that, independent of $\mathrm{Ca}^{2+}$ influx, causes $\mathrm{G}$-protein activation, which subsequently leads to $\mathrm{Ca}^{2+}$ release from intracellular stores via phospholipase $\mathrm{C}$ and $\mathrm{IP}_{3}$-receptor activation [6]. It remains to be determined whether the voltage-sensitive $\mathrm{Ca}^{2+}$ release mechanism in our study utilizes the same signaling pathway or whether the plasmalemmal voltagesensor directly interacts with the $\mathrm{IP}_{3}$ receptor in the ER membrane. The slow rise in cytosolic $\left[\mathrm{Ca}^{2+}\right]$ during prolonged depolarizations in the absence of external $\mathrm{Ca}^{2+}$ suggests the involvement of intermediary steps in transducing the electrical signal into a $\mathrm{Ca}^{2+}$ release from intercellular stores. Moreover, dihydropyridine receptors have previously been reported to act as voltage sensors for a voltage-dependent, $\mathrm{IP}_{3}$ receptor-mediated, slow $\mathrm{Ca}^{2+}$ signal in skeletal muscle cells [20]. A model was proposed in which the dihydropyridine receptor decodes the electrical signal into G-protein-dependent activation of phospholipase $\mathrm{C}$ to produce $\mathrm{IP}_{3}$, which then diffuses to $\mathrm{IP}_{3}$ receptors located on the ER and nuclear membrane, ultimately activating intracellular signaling cascades. Although our experiments provide no evidence for a role of dihydropyridine receptors as voltage-sensors in depolarization-evoked $\mathrm{Ca}^{2+}$ release in sympathetic ganglion neurons, our data suggests that both cell types share the signaling events downstream of their respective voltage-sensor.

Although 2-APB has been shown previously to inhibit $\mathrm{IP}_{3}$-mediated $\mathrm{Ca}^{2+}$ release in neurons [31], it also exerts unspecific effects on $\mathrm{Ca}^{2+}$ entry in non-excitable cell types, e.g. via blockade of cation-selective channels encoded by the by transient receptor potential (TRP) genes [32]. However, our observation that xestospongin $\mathrm{C}$ at a concentration that has been shown previously to specifically inhibit $\mathrm{IP}_{3}$ receptor signaling in a variety of mammalian cell types $[33,34]$, similarly suppressed depolarization-induced increases in $\left[\mathrm{Ca}^{2+}\right]_{\mathrm{i}}$ in the absence of external $\mathrm{Ca}^{2+}$ support our conclusion that depolarization-evoked rises in $\left[\mathrm{Ca}^{2+}\right]$ require functional $\mathrm{IP}_{3}$ receptors.

\section{Potential function of voltage-induced $\mathrm{Ca}^{2+}$ release in sympathetic neurons}

Voltage-induced $\mathrm{Ca}^{2+}$ release constitutes a novel mechanism by which adult sympathetic ganglion neurons couple electrical activity to graded rises in intracellular $\left[\mathrm{Ca}^{2+}\right]$. The extent to which this mechanism contributes to the increase in $\left[\mathrm{Ca}^{2+}\right]$ that normally occurs in response to single or repetitive action potentials remains to be quantitated. Eltit and co-workers previously demonstrated that tetanic stimulation of skeletal myotubes in the absence of extracellular $\mathrm{Ca}^{2+}$ gives rise to long-lasting, $\mathrm{IP}_{3}$-generated, slow $\mathrm{Ca}^{2+}$ signals both in the nucleus and cytoplasm [34]. It will be interesting to determine whether repetitive electrical discharge of sympathetic ganglion neurons, such as occurring physiologically in situ, also results in slow $\mathrm{Ca}^{2+}$ signals similar to those evoked by high $\left[\mathrm{K}^{+}\right]_{\mathrm{e}}$ in the present study.

Although the magnitude of the depolarization-induced global $\mathrm{Ca}^{2+}$ transient is small compared to that of a transient elicited in normal $\left[\mathrm{Ca}^{2+}\right]_{\mathrm{e}}$, it is possible that $\mathrm{Ca}^{2+}$ is released into microdomains in which it may exert strong effects on exocytosis and/or $\mathrm{Ca}^{2+}$-sensitive ion channels and enzymes, ultimately altering excitability, energy homeostasis, and transcriptional activity of the neuron. With regard to the latter, the elevations in nuclear fluo-4 fluorescence 
that were observed to occur concomitantly with those in the cytosol both in 2 and $0 \mathrm{mM}$ $\left[\mathrm{Ca}^{2+}\right]_{\mathrm{i}}$, may play a role in transcriptional regulation [10]. The magnitude of depolarizationinduced changes in nuclear fluo-4 fluorescence intensity in $2 \mathrm{mM}\left[\mathrm{Ca}^{2+}\right]_{\mathrm{e}}$ often reached saturation using gain settings that were optimized to monitor cytosolic fluorescence, precluding simultaneous measurements in both compartments.

Small elevations in cytosolic $\mathrm{Ca}^{2+}$ like those arising as a consequence depolarization-evoked $\mathrm{IP}_{3}$-recpetor stimulation, may enhance the $\mathrm{Ca}^{2+}$-sensitivity of nearby ryanodine receptors, thereby converting the cytoplasm in an excitable medium capable of producing regenerative $\mathrm{Ca}^{2+}$ responses.

\section{Supporting Information}

S1 Fig. Effect of cadmium, a non-selective blocker of voltage-gated $\mathrm{Ca}^{2+}$ channels, on high $\left[\mathrm{K}^{+}\right]_{\mathrm{e}}$-induced cytosolic $\mathrm{Ca}^{2+}$ transients in postganglionic sympathetic neurons. $\mathrm{A}$ and $\mathrm{B}$ : Family of current traces recorded from an isolated sympathetic neuron in the absence (A) and presence of $300 \mu \mathrm{M} \mathrm{CdCl}_{2}$ in the external solution. Currents were evoked by 200 -ms voltage steps, ranging from -70 to $+50 \mathrm{mV}$ in $10-\mathrm{mV}$ increments. C: Peak $I B a$-voltage relationship for the cadmium-sensitive (circles) and-resistant (squares) currents shown in $\mathrm{A}$ and $\mathrm{B} . \mathrm{CdCl} 2$ eliminated all inward currents.

(TIF)

\section{Author Contributions}

Conceived and designed the experiments: MR. Performed the experiments: HS WT BL WT PC MR. Analyzed the data: HS WT MR. Wrote the paper: MR.

\section{References}

1. Berridge MJ. Neuronal calcium signaling. Neuron. 1998; 21(1): 13-26. PMID: 9697848

2. Grienberger $C$, Konnerth A. Imaging calcium in neurons. Neuron. 2012; 73(5): 862-885. doi: 10.1016/j. neuron.2012.02.011 PMID: 22405199

3. Kim S, Yun HM, Baik JH, Chung KC, Nah SY, Rhim H. Functional interaction of neuronal Cav1.3 L-type calcium channel with ryanodine receptor type 2 in the rat hippocampus. J Biol Chem. 2007; 282(45): 32877-32889. PMID: 17823125

4. De Crescenzo V, Fogarty KE, Zhuge R, Tuft RA, Lifshitz LM, Carmichael J, et al. Dihydropyridine receptors and type 1 ryanodine receptors constitute the molecular machinery for voltage-induced $\mathrm{Ca}^{2+}$ release in nerve terminals. J Neurosci. 2006; 26(29): 7565-7574. PMID: 16855084

5. Ouardouz M, Nikolaeva MA, Coderre E, Zamponi GW, McRory JE, Trapp BD, et al. Depolarizationinduced $\mathrm{Ca}^{2+}$ release in ischemic spinal cord white matter involves L-type $\mathrm{Ca}^{2+}$ channel activation of ryanodine receptors. Neuron. 2003; 40(1): 53-63. PMID: 14527433

6. Ryglewski S, Pflueger HJ, Duch C. Expanding the neuron's calcium signaling repertoire: intracellular calcium release via voltage-induced PLC and IP ${ }_{3} R$ activation. PLoS Biol. 2007; 5(4): e66. PMID: 17341135

7. Kukwa W, Macioch T, Szulczyk PJ. Stellate neurones innervating the rat heart express $N, L$ and $P / Q$ calcium channels. J Auton Nerv Syst. 1998; 74(2-3): 143-151. PMID: 9915630

8. Namkung Y, Smith SM, Lee SB, Skrypnyk NV, Kim HL, Chin H, et al. Targeted disruption of the $\mathrm{Ca}^{2+}$ channel beta3 subunit reduces $\mathrm{N}$ - and $\mathrm{L}$-type $\mathrm{Ca}^{2+}$ channel activity and alters the voltage-dependent activation of P/Q-type $\mathrm{Ca}^{2+}$ channels in neurons. Proc Natl Acad Sci U S A. 1998; 95(20): 1201012015. PMID: 9751781

9. Martínez-Pinna J, Lamas JA, Gallego R. Calcium current components in intact and dissociated adult mouse sympathetic neurons. Brain Res. 2002; 951(2): 227-236. PMID: 12270501

10. Wheeler DG, Barrett CF, Groth RD, Safa P, Tsien RW. CaMKII locally encodes L-type channel activity to signal to nuclear CREB in excitation-transcription coupling. J Cell Biol. 2008; 183(5): 849-863. doi: 10.1083/jcb.200805048 PMID: 19047462 
11. Akita $\mathrm{T}$, Kuba K. Functional triads consisting of ryanodine receptors, $\mathrm{Ca}^{2+}$ channels, and $\mathrm{Ca}^{2+}$-activated $\mathrm{K}^{+}$channels in bullfrog sympathetic neurons. Plastic modulation of action potential. J Gen Physiol. 2000; 116(5): 697-720. PMID: 11055998

12. Albrecht MA, Colegrove SL, Hongpaisan J, Pivovarova NB, Andrews SB, Friel DD. Multiple modes of calcium-induced calcium release in sympathetic neurons I: attenuation of endoplasmic reticulum $\mathrm{Ca}^{2+}$ accumulation at low $\left[\mathrm{Ca}^{2+}\right]_{i}$ during weak depolarization. J Gen Physiol. 2001; 118(1): 83-100. PMID: 11429446

13. Li BY, Schild JH. Electrophysiological and pharmacological validation of vagal afferent fiber type of neurons enzymatically isolated from rat nodose ganglia. J Neurosci Methods. 2007; 164(1): 75-85. PMID: 17512602

14. Friel DD, Tsien RW. A caffeine- and ryanodine-sensitive $\mathrm{Ca}^{2+}$ store in bullfrog sympathetic neurones modulates effects of $\mathrm{Ca}^{2+}$ entry on [Ca $\left.{ }^{2+}\right]_{i}$. J Physiol. 1992; 450: 217-246. PMID: 1432708

15. Schoenmakers TJ, Visser GJ, Flik G, Theuvenet AP. CHELATOR: an improved method for computing metal ion concentrations in physiological solutions. Biotechniques. 1992; 12(6): 870-879. PMID: 1642895

16. Estève E, Eltit JM, Bannister RA, Liu K, Pessah IN, Beam KG, et al. A malignant hyperthermia-inducing mutation in RYR1 (R163C): alterations in $\mathrm{Ca}^{2+}$ entry, release, and retrograde signaling to the DHPR. J Gen Physiol. 2010; 135(6): 619-628. doi: 10.1085/jgp.200910328 PMID: 20479110

17. Satoh H, Delbridge LM, Blatter LA, Bers DM. Surface: volume relationship in cardiac myocytes studied with confocal microscopy and membrane capacitance measurements: species-dependence and developmental effects. Biophys J. 1996; 70(3): 1494-1504. PMID: 8785306

18. Thayer SA, Hirning LD, Miller RJ. The role of caffeine-sensitive calcium stores in the regulation of the intracellular free calcium concentration in rat sympathetic neurons in vitro. Mol Pharmacol. 1988; 34(5): 664-673. PMID: 3193957

19. Beam KG, Bannister RA. Looking for answers to EC coupling's persistent questions. J Gen Physiol. 2010; 136(1): 7-12. doi: 10.1085/jgp.201010461 PMID: 20584887

20. Araya R, Liberona JL, Cárdenas JC, Riveros N, Estrada M, Powell JA, et al. Dihydropyridine receptors as voltage sensors for a depolarization-evoked, $\mathrm{IP}_{3} \mathrm{R}$-mediated, slow calcium signal in skeletal muscle cells. J Gen Physiol. 2003; 121(1): 3-16. PMID: 12508050

21. Nimmrich V, Gross G. P/Q-type calcium channel modulators. Br J Pharmacol. 2012; 167(4): 741-759. doi: 10.1111/j.1476-5381.2012.02069.x PMID: 22670568

22. Bannister RA, Pessah IN, Beam KG. The skeletal L-type $\mathrm{Ca}^{2+}$ current is a major contributor to excitation-coupled $\mathrm{Ca}^{2+}$ entry. J Gen Physiol. 2009; 133(1): 79-91. doi: 10.1085/jgp.200810105 PMID: 19114636

23. Hille B. Ion channels of excitable membranes. 3rd ed. Sunderland: Sinauer Associates, MA; 2001.

24. Belluzzi O, Sacchi O. Calcium currents in the normal adult rat sympathetic neurone. J Physiol. 1989; 412: 493-512. PMID: 2557430

25. Usai C, Barberis A, Moccagatta L, Marchetti C. Pathways of cadmium influx in mammalian neurons. J Neurochem. 1999; 72(5): 2154-2161. PMID: 10217297

26. Hinkle PM, Shanshala ED 2nd, Nelson EJ. Measurement of intracellular cadmium with fluorescent dyes. Further evidence for the role of calcium channels in cadmium uptake. J Biol Chem. 1992; 267 (35): 25553-25559. PMID: 1281160

27. Blumenstein Y, Maximyuk OP, Lozovaya N, Yatsenko NM, Kanevsky N, Krishtal O, et al. Intracellular $\mathrm{Na}^{+}$inhibits voltage-dependent $\mathrm{N}$-type $\mathrm{Ca}^{2+}$ channels by a $\mathrm{G}$ protein betagamma subunit-dependent mechanism. J Physiol. 2004; 556(Pt 1): 121-134. PMID: 14742725

28. Polo-Parada L, Korn SJ. Block of $\mathrm{N}$-type calcium channels in chick sensory neurons by external sodium. J Gen Physiol. 1997; 109(6): 693-702. PMID: 9222896

29. Parri HR, Crunelli V. Sodium current in rat and cat thalamocortical neurons: role of a non-inactivating component in tonic and burst firing. J Neurosci. 1998; 18(3): 854-867. PMID: 9437007

30. Okamura Y, Murata Y, Iwasaki H. Voltage-sensing phosphatase: actions and potentials. J Physiol. 2009; 587(Pt 3): 513-520. doi: 10.1113/jphysiol.2008.163097 PMID: 19074969

31. Bootman MD, Collins TJ, Mackenzie L, Roderick HL, Berridge MJ, Peppiatt CM. 2-aminoethoxydiphenyl borate (2-APB) is a reliable blocker of store-operated $\mathrm{Ca}^{2+}$ entry but an inconsistent inhibitor of InsP $_{3}$-induced $\mathrm{Ca}^{2+}$ release. FASEB J. 2002; 16(10): 1145-1150. PMID: 12153982

32. Xu SZ, Zeng F, Boulay G, Grimm C, Harteneck C, Beech DJ. Block of TRPC5 channels by 2-aminoethoxydiphenyl borate: a differential, extracellular and voltage-dependent effect. Br J Pharmacol. 2005; 145(4): 405-414. PMID: 15806115 
33. Bofill-Cardona E, Vartian N, Nanoff C, Freissmuth M, Boehm S. Two different signaling mechanisms involved in the excitation of rat sympathetic neurons by uridine nucleotides. Mol Pharmacol. 2000; 57 (6): 1165-1172. PMID: 10825387

34. Eltit JM, Hidalgo J, Liberona JL, Jaimovich E. Slow calcium signals after tetanic electrical stimulation in skeletal myotubes. Biophys J. 2004; 86(5): 3042-3051. PMID: 15111418 